\title{
Epigenetic profiling of the antitumor natural product psammaplin A and its analogues
}

\author{
José García ${ }^{a}$, Gianluigi Franci ${ }^{\text {b,f }}$, Raquel Pereira ${ }^{\mathrm{a}}$, Rosaria Benedetti ${ }^{\mathrm{b}, \mathrm{c}, \mathrm{e}}$, Angela Nebbioso ${ }^{\mathrm{b}}$, \\ Fátima Rodríguez-Barrios ${ }^{\mathrm{a}}$, Hinrich Gronemeyer ${ }^{\mathrm{d}}$, Lucia Altucci ${ }^{\mathrm{b}, \mathrm{f}, *}$, Angel R. de Lera ${ }^{\mathrm{a}, *}$ \\ Departamento de Química Orgánica, Universidade de Vigo, 36310 Vigo, Spain \\ ${ }^{\mathrm{b}}$ Dipartimento di Patologia generale, Seconda Università di Napoli, Vico L. De Crecchio 7, 80138 Napoli, Italy \\ ${ }^{\mathrm{C}}$ Università di Napoli Federico II, Dipartimento di Chimica Organica e Biochimica, Italy

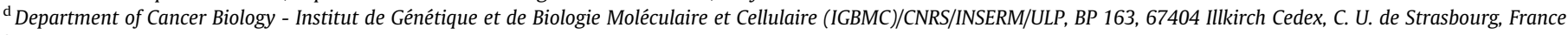 \\ e Università di Napoli Federico II, Dipartimento di Fisica, 6, CNR-IGB, Via P. Castellino, 80100, Napoli, , Italy \\ ${ }^{\mathrm{f}}$ CNR-IGB, Via Pietro Castellino 80100 Napoli, Italy
}

\section{A R T I C L E I N F O}

\section{Article history:}

Received 30 September 2010

Accepted 8 December 2010

Available online 15 December 2010

\section{Keywords:}

Psammaplin A

Epigenetics

HDAC

DNMT

Total synthesis

Natural products

\begin{abstract}
A B S T R A C T
A collection of analogues of the dimeric natural product psammaplin A that differ in the substitution on the (halo)tyrosine aryl ring, the oxime and the diamine connection has been synthesized. The effects on cell cycle, induction of differentiation and apoptosis of the natural-product inspired series were measured on the human leukaemia U937 cell line. Epigenetic profiling included induction of p2 ${ }^{\text {WAF1 }}$, effects on global $\mathrm{H} 3$ histone and tubulin acetylation levels as well as in vitro enzymatic assays using HDAC1, DNMT1, DNMT3A, SIRT1 and a peptide domain with p300/CBP HAT activity. Whereas the derivatives of psammaplin A with modifications in the length of the connecting chain, the oxime bond and the disulfide unit showed lower potency, the analogues with changes on the bromotyrosine ring exhibited activities comparable to those of the parent compound in the inhibition of HDAC1 and in the induction of apoptosis. The lack of HDAC1 activity of analogues modified on the disulfide bond suggests that its cleavage must occur in cells to produce the monomeric $\mathrm{Zn}^{2+}$-chelating thiol. This assumption is consistent with the molecular modelling of the complex of psammaplin A thiol with h-HDAC8. Only a weak inhibition of DNMT1, DNMT3A and residual activities with SIRT1 and a p300/CBP HAT peptide were measured for these compounds.
\end{abstract}

(c) 2010 Elsevier Ltd. All rights reserved.

\section{Introduction}

Psammaplin A (1, PsA, Scheme 1) is a symmetrical disulfide dimer derived from the condensation of modified tyrosine and cysteine units ${ }^{1}$ (for a proposal of its biogenesis, see 2,3). Although it was first isolated in 1987 from an unidentified sponge ${ }^{4}$ and from Psammaplysilla sp., ${ }^{5,6}$ PsA is found, together with biogenetically-related congeners, in several Verongidas ${ }^{2,3,6-10}$ and in some associations of these species. ${ }^{11,12}$

Antibacterial and antitumor activities have been reported for PsA. The in vitro antibacterial activity of PsA against both Staphylococcus aureus (SA) and methicillin-resistant Staphylococcus aureus (MRSA) was considered the result of the inhibition of DNA gyrase $\mathrm{e}^{13}$ and induced arrest of bacterial DNA synthesis. PsA also inhibits topoisomerase II (topo II), ${ }^{14}$ farnesyl protein transferase, ${ }^{8}$ leucine aminopeptidase $^{8}$ mycothiol-S-conjugate amidase, ${ }^{15}$ chitinase, ${ }^{10}$ Pol $\alpha$-primase, ${ }^{16}$ PPAR $\gamma^{17-20}$ and mammalian aminopeptidase $\mathrm{N}$

\footnotetext{
* Corresponding authors.

E-mail addresses: lucia.altucci@unina2.it (L. Altucci), qolera@uvigo.es (Angel R. de Lera).
}

(APN). ${ }^{21}$ Targeting multiple proteins that impact on DNA topology, DNA replication, transcription, apoptosis, tumor invasion, and angiogenesis likely contributes to the significant cytotoxicity displayed by PsA in human lung (A549), ovarian (SKOV- 3), skin (SK-MEL-2), CNS (XF498), and colon (HCT15) cancer cell lines. ${ }^{12}$

PsA was also reported to inhibit in vitro the chromatin-modifying enzymes histone deacetylase (HDAC) and DNA methyl transferase (DNMT). ${ }^{3}$ HDAC and DNMT are epigenetic enzymes that catalyze the covalent modifications of histone proteins and DNA in chromatin, ${ }^{22}$ and therefore they are considered prime new targets $^{23}$ for the treatment and prevention of cancer ${ }^{24-34}$ and other diseases. ${ }^{35}$ The modification of chromatin is thus an addition to the list of potential mechanisms involved in the anticancer actions of the natural product PsA.

Histone acetylation is a dynamic process in which a cellular steady state is maintained by the opposing activities of histone acetyltransferases (HATs) and deacetylase enzymes (HDAC) acting at the $\varepsilon$-amino groups of evolutionally conserved lysine residues located at the histone N-termini. HATs transfer the acetyl moiety from acetyl CoA to the histone lysine residues whereas HDACs catalyze their removal. Individual HATs and HDACs display distinct 


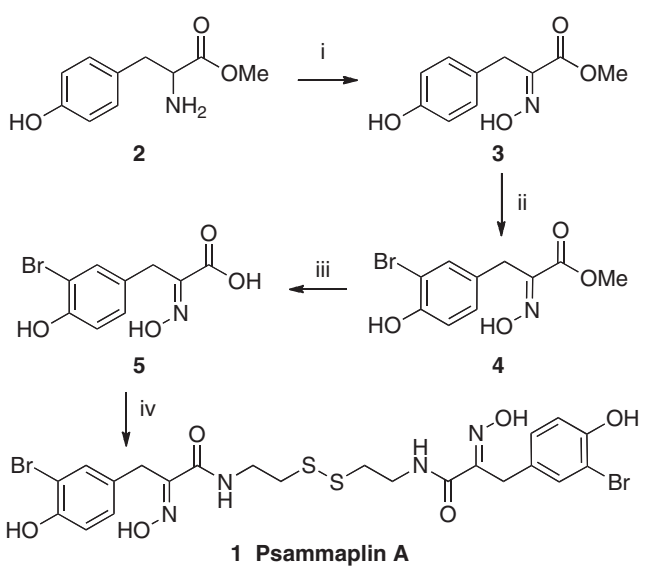

Scheme 1. Reagents and conditions: (i) $\mathrm{Na}_{2} \mathrm{WO}_{4}, \mathrm{H}_{2} \mathrm{O}_{2}, 25^{\circ} \mathrm{C}, 3 \mathrm{~h}$ (63\%); (ii) NBS, $\mathrm{CH}_{3} \mathrm{CN}, 25^{\circ} \mathrm{C}, 2 \mathrm{~h}$ (82\%); (iii) LiOH, THF- $\mathrm{H}_{2} \mathrm{O}, 23^{\circ} \mathrm{C}, 12 \mathrm{~h}$ (99\%); (iv) DCC, $\mathrm{N}$ hydroxyphthalimide, $\mathrm{Et}_{3} \mathrm{~N}$, cystamine, 1,4-dioxane, $\mathrm{MeOH}, 25{ }^{\circ} \mathrm{C}, 12 \mathrm{~h}(60 \%)$.

specificities for certain individual lysine residues and particular histones. Although the factors responsible for the specificity are poorly understood they might reflect different biological functions of the various enzymes. Regardless of the details, it is widely accepted that histone acetylation is essential to establish a transcriptionally competent state of chromatin ${ }^{22}$ and consequently contributes to the gene activation/gene repression transcriptional status of cells. Two histone deacetylase inhibitors (HDACis), suberoylanilide hydroxamic acid (SAHA, vorinostat, Zolinza ${ }^{\circledR}$ ), and FK228 (romidepsin, Istodax ${ }^{\circledR}$ ) are used as therapy for cutaneous T-cell lymphoma, ${ }^{36}$ and several others are currently undergoing clinical trials as potential targeted cancer chemotherapeutic agents. $^{37-41}$

In eukaryotes DNMTs catalyze the addition of methyl groups from $S$-adenosyl-L-methionine (SAM) to the C5 position of cytosine bases within the $\mathrm{CpG}$-rich islands in DNA. Methylation of DNA is an epigenetic mark associated to a repressed chromatin state which inhibits gene transcription. ${ }^{42,43}$ Several tumour supressor genes are hypermethylated in tumours, which suggest a link between aberrant DNA methylation and cancer. ${ }^{44-47}$ DNA methyl transferase inhibitors (DNMTis) ${ }^{48}$ structurally related to cytidine (5-azacytidine, Vidaza ${ }^{\circledR}$ and 5-aza-deoxycytidine, Dacogen ${ }^{\circledR}$ ) are already in the clinic for the treatment of myelodysplastic syndrome. ${ }^{49}$

Since histone acetylation and DNA methylation play a key role in the pathophysiology of cells, dual inhibitors of HDAC or DNMT are therapeutically more appealing than combination of these drugs. ${ }^{50,51}$ We thus became intrigued by the reports on the potent activity of psammaplin $\mathrm{A}(\mathbf{1})$ in the inhibition of these two epigenetic enzymes (HDAC: $\mathrm{IC}_{50}=4.2 \mathrm{nM}$; DNMT: $\mathrm{IC}_{50}=18.6 \mathrm{nM}$ using in vitro cell-free enzyme assays $)^{3}$ as well as by the in vitro and in vivo inhibition of tumour growth induced by this natural product. ${ }^{20}$ Despite the reports indicating some drawbacks for the development of $\mathbf{1}$ as a drug due to its poor physiological stability, ${ }^{15,21,52}$ we undertook the synthesis of a family of analogues with the aim to discover more potent and selective derivatives of $\mathbf{1}$ as well as to shed light into the mechanism of epigenetic inhibition by 1. Apart from the work of Nicolaou focused on antibacterial activities, no structure-activity relationship studies of the anticancer activities of PsA analogues have been reported, which are necessary for an eventual lead optimization project within this class of modified tetrapeptides.

\section{Chemistry. Synthesis of psammaplin A and derivatives}

All previous synthetic approaches to 1 have focused on the final construction of the dimeric disulfide structure by condensation of the corresponding carboxylic acid with the symmetrical diamine cystamine. Both Hoshino et al. ${ }^{53}$ and Nicolaou et al..$^{54,55}$ installed the oxime function after the synthesis of the corresponding pyruvic acid derived from L-tyrosine, in a sequence that afforded $\mathbf{1}$ in moderate overall yields. Nicolaou then screened in antibacterial assays a 3828-membered library of heterodimeric psammaplin A analogues ${ }^{15}$ obtained from symmetrical precursors by combinatorial scrambling via catalytically-induced disulfide exchange reactions. A recently described three-step (43\% overall yield) synthesis of PsA 1 starts from the considerably more expensive and less versatile 4-hydroxyphenylpyruvic acid. ${ }^{56}$

We modified the above synthesis of $\mathbf{1}$ by performing the bromination of the phenol ring on the corresponding oxime $\mathbf{3}$ (Scheme 1). ${ }^{57}$ As shown on Scheme 1, the amino group of L-tyrosine $\mathbf{2}$ was oxidized to the hydroxyimino ester 3 in $60 \%$ yield using $\mathrm{Na}_{2} \mathrm{WO}_{4}$ and $\mathrm{H}_{2} \mathrm{O}_{2}$ in ethanol. ${ }^{58}$ A monobrominated product 4 was obtained by treatment of 3 with one equivalent of $\mathrm{NBS}$ in $\mathrm{CH}_{3} \mathrm{CN}$ at $25{ }^{\circ} \mathrm{C},{ }^{58,59}$ with no evidence of formation of the dibromo derivative or the dibrominated spirocyclic isoxazoline. ${ }^{57}$ After saponification of $\mathbf{4}$ the carboxylic acid 5 was coupled with cystamine using Hoshino's conditions. ${ }^{53}$ The overall yield for the synthetic sequence is $29 \%$, with a slight improvement over the two routes previously described from L-tyrosine $\mathbf{2}$. The synthetic scheme is advantageous for the preparation of diverse PsA analogues starting from commercial tyrosine derivatives.

Using the methodology depicted on Scheme 1, the synthesis of PsA homologues containing from three to six methylene units was completed, albeit in low yields (Scheme 2), using the non-commercial diamines $\mathbf{6 a - d}$, which were synthesized following a general methodology. ${ }^{60}$

Similarly, PsA analogues that preserve the native connecting cystamine unit but differ in the substituents at the aryl ring (Scheme 3 ) were synthesized using either commercially available tyrosine derivatives or the synthetic halogenated analogues (with bromine or iodine at $\mathrm{C} 3$ ) after oxidation of the amine to the oxime (Scheme 3). Some compounds of the series (11a, 11c, 11d and 11e) have previously been described by Nicolaou on his search for new antibacterial agents. ${ }^{55}$ Bromopsammaplin A 11f is also a natural product isolated from an association of the sponges Jaspis wondoensis and Poecillastra wondoensis. ${ }^{12}$

Condensation of acid 5 with amines 12 and 14a-c (Scheme 4) provided analogues 13 and 15a-c which were designed to further our understanding of the mechanism underlying the biological activity of the parent PsA as HDAC inhibitor. The dimer 13 contains an ethylene group replacing the disulfide bond functionality. Products $\mathbf{1 5 b}, \mathbf{c}$ are monomers that have, respectively, methyl ether and methyl sulfide as end groups. The primary alcohol $\mathbf{1 6}$ was obtained by acidic ( 7:2:1 THF/ $\left.\mathrm{HCO}_{2} \mathrm{H} / \mathrm{H}_{2} \mathrm{O}\right)$ deprotection of silyl ether $\mathbf{1 5 a}$.

The derivative lacking the oxime was also of interest to reveal whether this functional group is critical for the epigenetic activity of $\mathbf{1}$. Compound $\mathbf{2 0}$ was prepared as described on Scheme 5. The bromination of methyl 3-(4-hydroxyphenyl)propanoate using the

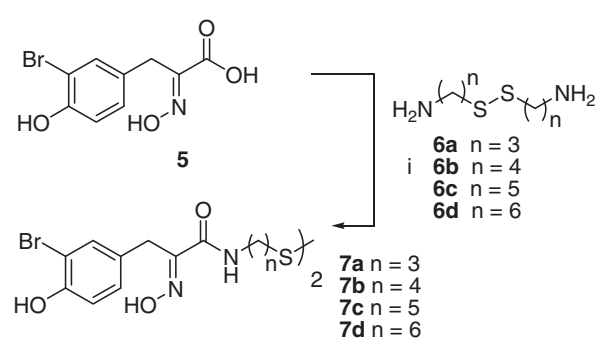

Scheme 2. Reagents and conditions: (i) DCC, $N$-hydroxyphthalimide, $\mathrm{Et}_{3} \mathrm{~N}$, diamine 6, 1,4-dioxane, $\mathrm{MeOH}, 25{ }^{\circ} \mathrm{C}, 12$ h (7a, 16\%; 7b, 21\%; 7c, 34\%; 7d, 14\%). 


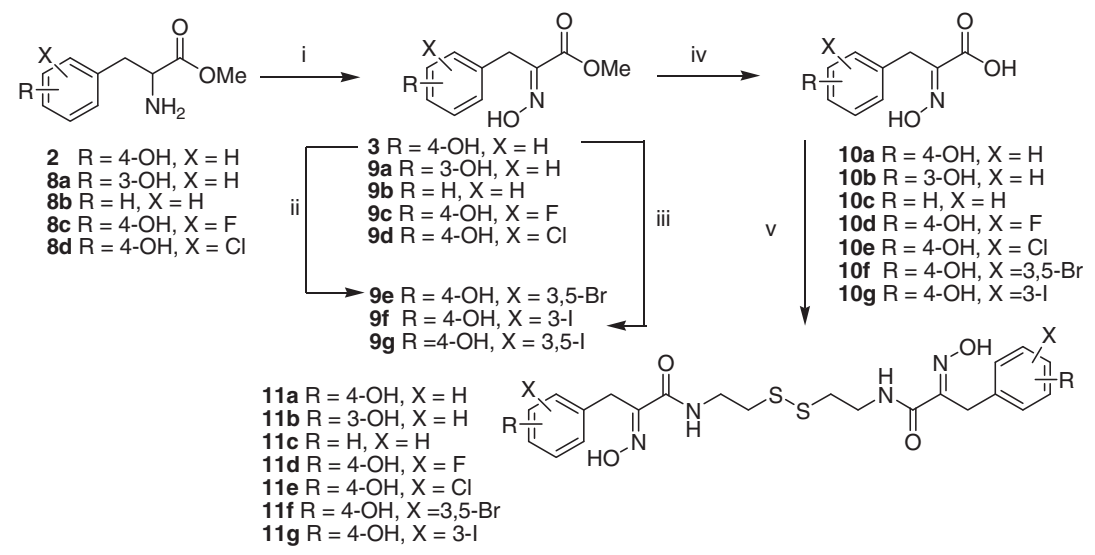

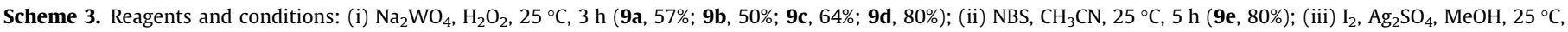

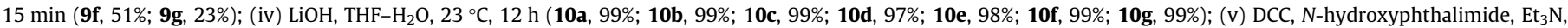
cystamine, 1,4-dioxane, $\mathrm{MeOH}, 25^{\circ} \mathrm{C}, 12 \mathrm{~h}$ (11a, 46\%; 11b, 54\%; 11c, 15\%; 11d, 57\%; 11e, 57\%; 11f, 42\%; 11g, 52\%).
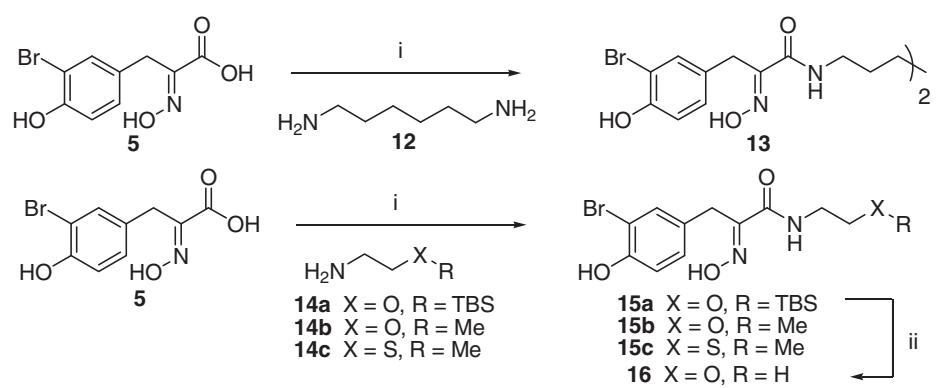

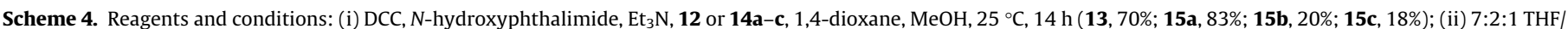
$\mathrm{HCO}_{2} \mathrm{H} / \mathrm{H}_{2} \mathrm{O}, 25^{\circ} \mathrm{C}, 14 \mathrm{~h}(76 \%)$.<smiles>[Y][Y10]([H])([H])[R]([H])[H]</smiles>

Scheme 5. Reagents and conditions: (i) NBS, DMF, $25^{\circ} \mathrm{C}, 5 \mathrm{~h}$ (18a, 56\%; 18b, 17\%); (ii) LiOH, THF- $\mathrm{H}_{2} \mathrm{O}, 23^{\circ} \mathrm{C}, 12 \mathrm{~h}$ (99\%); (ii) DCC, $\mathrm{N}$-hydroxyphthalimide, $\mathrm{Et}_{3} \mathrm{~N}$, cystamine, 1,4-dioxane, $\mathrm{MeOH}, 25^{\circ} \mathrm{C}, 14 \mathrm{~h}(40 \%)$.

conditions described for oxime 4 ( $\mathrm{NBS}$ in $\mathrm{CH}_{3} \mathrm{CN}$ ) yielded a mixture of mono- and dibromo derivatives, $\mathbf{1 8 a}$ and $\mathbf{1 8 b}$, respectively, in a 3:1 ratio. Hydrolysis of the former followed by the coupling of $\mathbf{1 9}$ with cystamine led to the desired disulfide $\mathbf{2 0}$ in moderate yield (Scheme 5).

Lastly the spirocyclic hexadienyl-isoxazoline 21, a potential metabolite of PsA ${ }^{1}$ could only be obtained, albeit in very low yield (5\%), by the oxidative-induced cyclization ${ }^{61}$ of PsA 1 with manganese(III) tris(acetylacetonate) (MTA ${ }^{62}$ (Scheme 6) after many other methods failed.

\section{Biological characterization}

Firstly, we focused on the reported inhibition of HDAC by PsA and the synthetic analogues, as well as on their effects on cell cycle, induction of differentiation and apoptosis on the U937 human

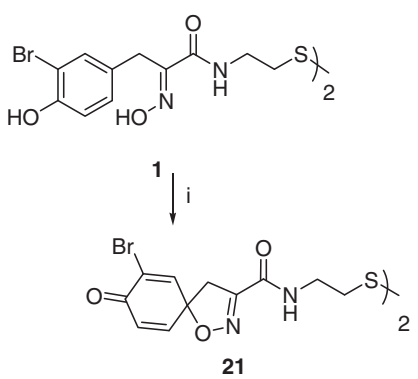

Scheme 6. Reagents and conditions: (i) $\mathrm{MTA}, \mathrm{CH}_{3} \mathrm{CN}, 25^{\circ} \mathrm{C}, 15 \mathrm{~h}(5 \%)$.

acute myeloid leukemia cell line. In vitro tests of the compounds at $5 \mu \mathrm{M}$ on human recombinant HDAC1, using SAHA as a positive control, confirmed the enzymatic inhibition of PsA 1 (Fig. 1A). In addition, some analogues (11a-e, $\mathbf{1 1 g}$ ) reduced the activity of HDAC1 more efficiently than $\mathbf{1}$. The other compounds of the series (7a-d, 11f, 13, 15b-c, 16, 20 and 21) did not noticeably affect HDAC1 activity. Compounds with longer chain connecting the disulfide to the hydroxyimino amide (7a-d) lack significant inhibitory activity. A similar result was observed for compounds having the disulfide replaced by methylene units (13) and for the monomers with either methyl ether -OMe, methyl thioether $(-\mathrm{SMe})$ or alcohol $(-\mathrm{OH})$ functionalities $(\mathbf{1 5 b}, \mathbf{1 5 c}$ and $\mathbf{1 6}$, respectively). In contrast, the inhibitory activity is maintained and even increased with compounds that preserve the general modified tetrapeptide scaffold of PsA regardless of the nature and pattern of the substituents at the aryl ring (11a-f). The more drastic change of the overall aryl ring structure imparted by the spirocycle together 


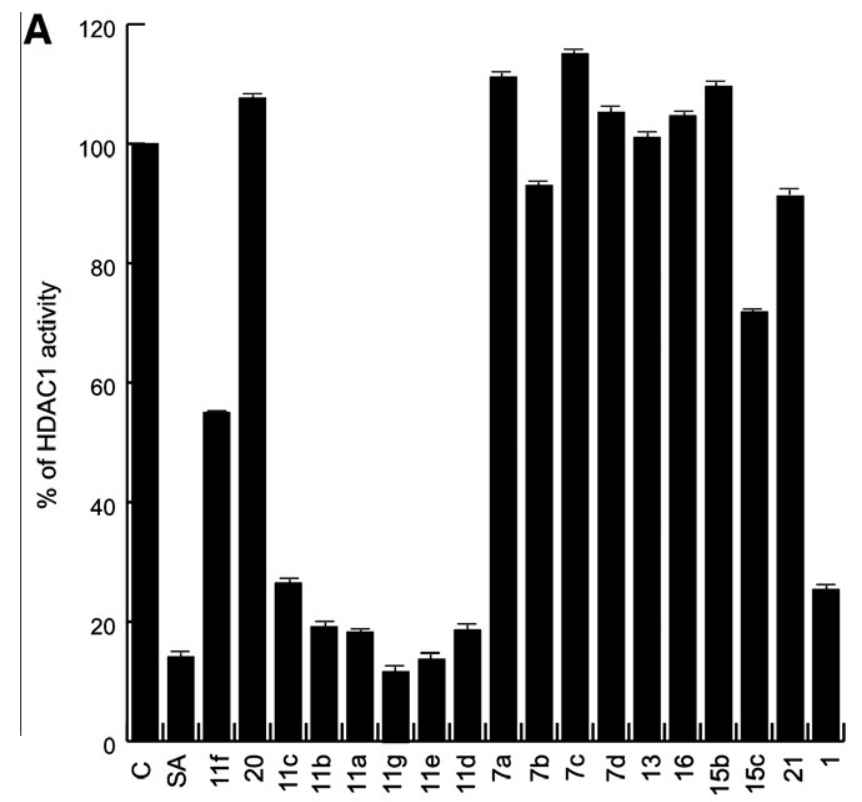

C

B
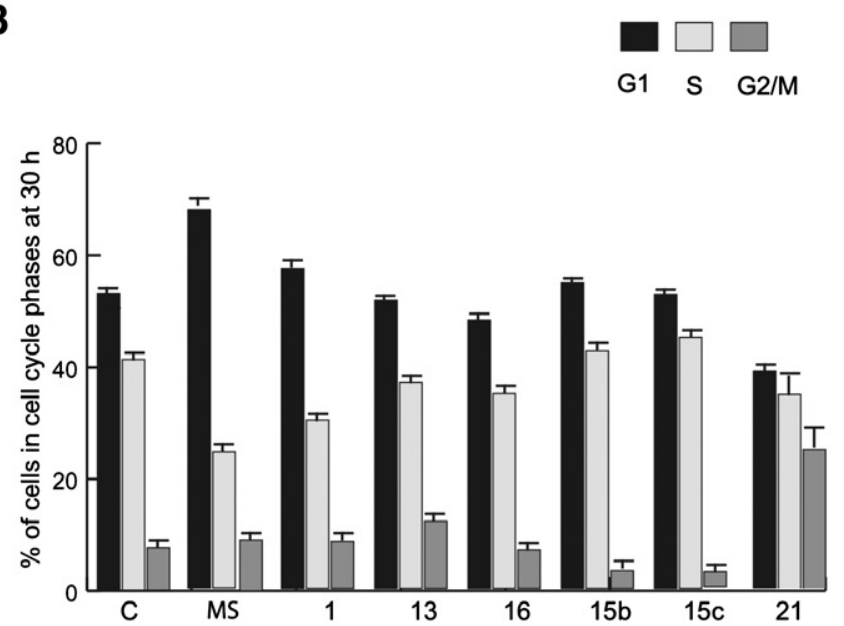
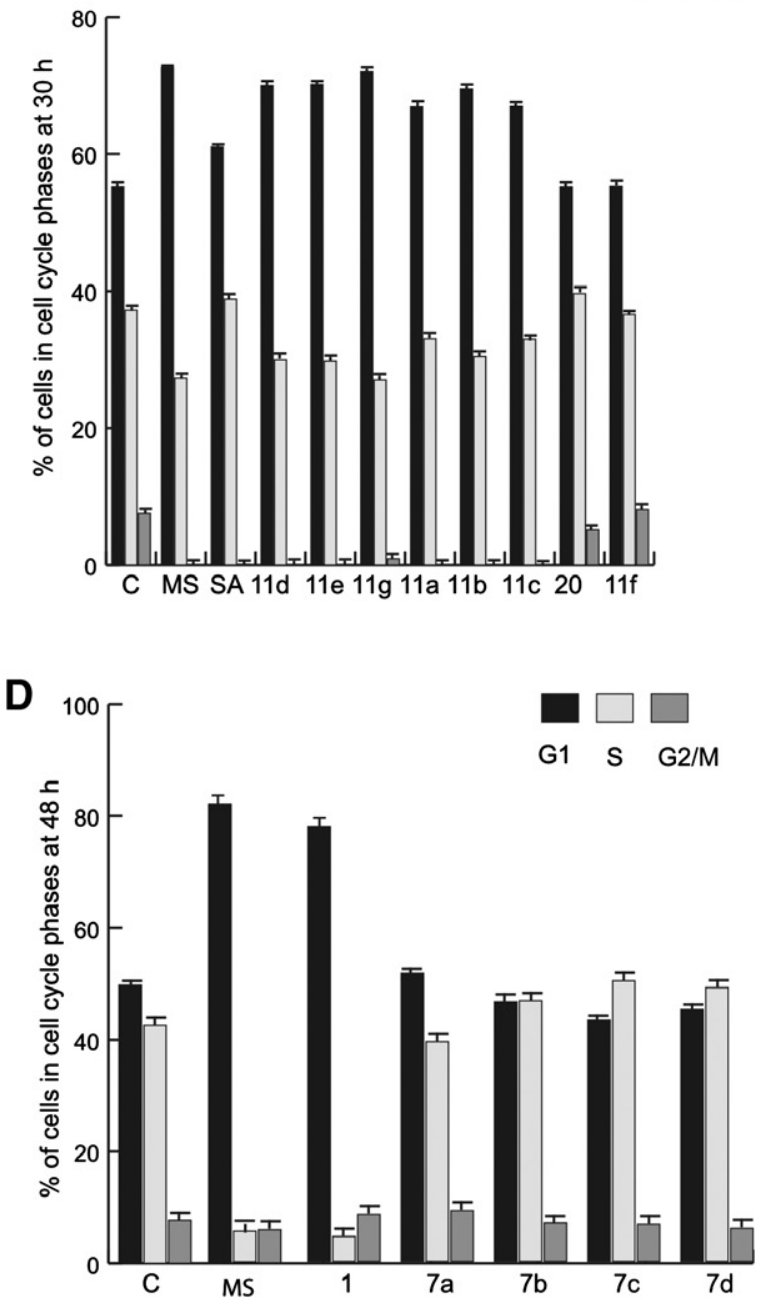

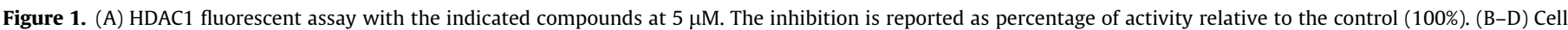
cycle analysis and apoptosis in U937 cells treated with the indicated compounds at $5 \mu \mathrm{M}$ for $30 \mathrm{~h}$. The data represent the media of independent duplicates.

with the reduction of flexibility and the lack of free oxime in derivative $\mathbf{2 1}$ led to substantial loss of HDAC inhibitory activity.

Cell-based assays were performed on the U937 myeloid leukemia cells to determine the anti-proliferative potential and the ability of the compounds to revert myeloid tumor cells to differentiated granulocytes. Cell cycle progression, differentiation and amount of cells that undergo apoptosis following treatment with PsA 1 and analogues $(5 \mu \mathrm{M})$ for 30,40 , and 48 h were determined (Figs. 1B and 2). Compared to the vehicle-treated cells and relative to the positive control represented by the known HDACis MS275 (HDAC1,2,3-selective) and SAHA (also HDAC6 inhibitor), ${ }^{63,64}$ only PsA 1 and some analogues induced cell cycle arrest in G1 (Fig. 1, panels B-D). In particular after $30 \mathrm{~h}$ PsA induced a time-dependent accumulation of U937 cells in the G1 phase (60\%), and analogues 11a-g and $\mathbf{2 0}$ showed even greater arrest (80\%), with values comparable to MS-275 (Fig. 1C). A clear correlation between the in vitro HDAC1 inhibition and the in vivo efficacy to induce cell cycle arrest was noticed for the most active compounds. Compound 21, on the other hand, appears to block cell cycle at $\mathrm{G} 2 / \mathrm{M}$. The remaining analogues gave no detectable activities on cell cycle progression even after longer $(48 \mathrm{~h})$ treatment regimes (Fig. 1B and D).
The percentage of apoptotic cells (measured as caspase 3 activation by FACS analysis) increased when U937 cells were treated with 1 and series 11a-g for $30 \mathrm{~h}$ (Fig. 2A). After $30 \mathrm{~h}$ induction with compounds 11a-e and $\mathbf{1 1 g}$ the percentage of apoptotic cells varied between $30 \%$ and $40 \%$. Other compounds, including bromopsammaplin A (11f), and the derivative lacking the oxime function 20, exhibited only minor effects even at longer incubation times $(40 \mathrm{~h})$. The results confirmed the in vitro findings since the most potent inducers of differentiation and apoptosis in U937 cells are the 11a-g series of ring-modified PsA analogues (with the exception of bromopsammaplin A 11f). Modifications in the chain length and the disulfide led to lower values of apoptosis, in agreement with the enzymatic assays. Interestingly, spiro derivative $\mathbf{2 1}$ showed comparable induction of apoptosis to parent 1.

The differentiation of myeloid precursors to granulocytes was determined by measuring the presence on the cell membrane of the granulocytic differentiation marker CD11c antigen, which is highly expressed only on mature granulocytes, monocytes and certain lymphocytes, but not significantly on myeloid committed precursor cells. After treating the U937 cells with the PsA analogues at $5 \mu \mathrm{M}$ for 30 and $40 \mathrm{~h}$, low differentiation levels 
A
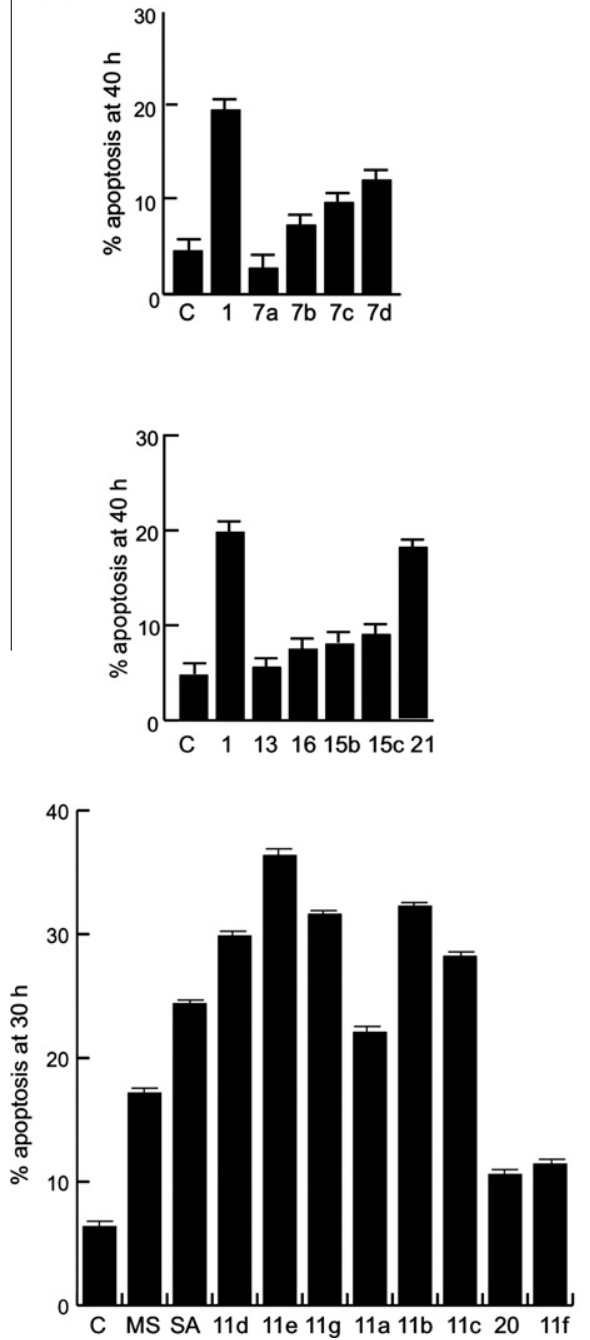

B
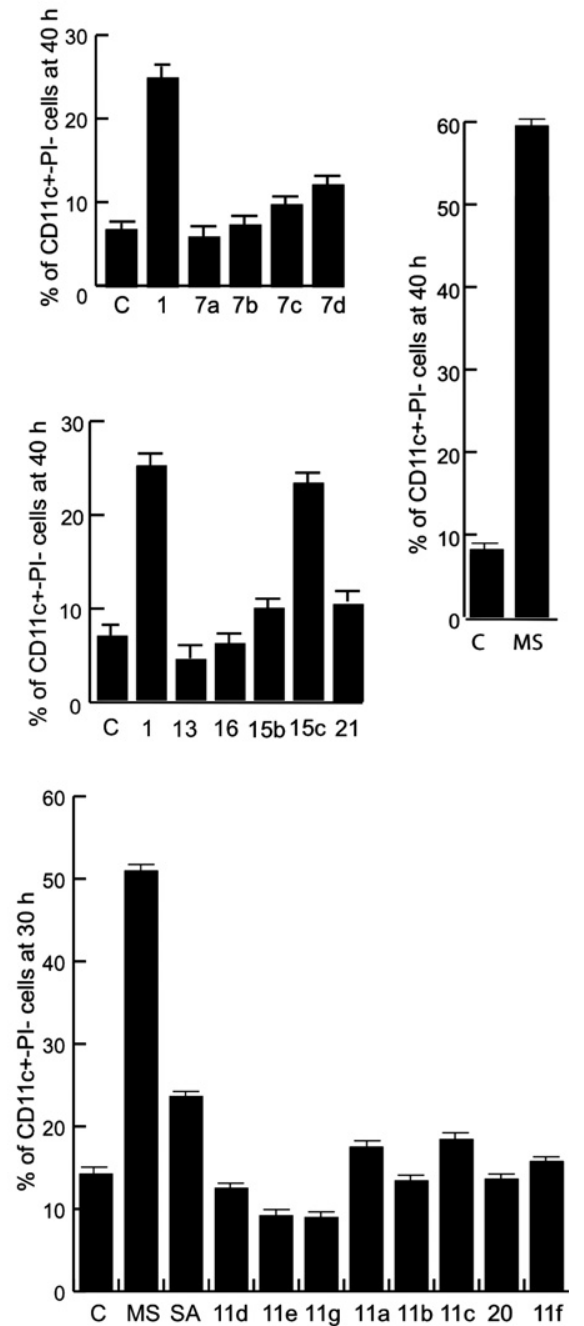

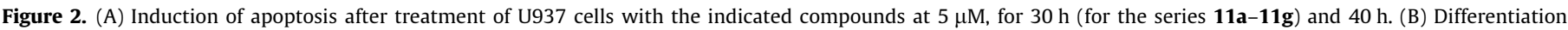

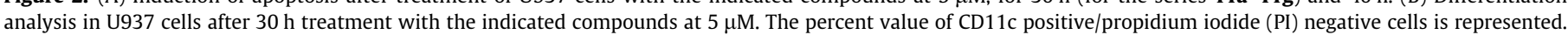
The data shown is the media of independent quadruplicates.

were measured (with the exception of parent 1 and methyl sulfide 15c) relative to control (Fig. $2 \mathrm{~B}$ ) and to the class I-selective HDACi MS-275.

We next determined the expression levels of $\mathrm{p} 21^{\mathrm{WAF} 1}$, which is involved in the mechanism of tumor suppression, as well as the global acetylation status of histone (histone H3) and non-histone proteins (tubulin), that are substrates of HDACs family members. The up-regulation of p21 WAF1 and the increase of tubulin acetylation levels were evaluated by Western blot analyses on total extracts after treating the U937 cells for $24 \mathrm{~h}$ with the compounds at $5 \mu \mathrm{M}$ (Fig. 3A-C). Compounds 7a-d, 13, 15b, 16 and 21 failed to increase both $\mathrm{p} 21^{\text {WAF1 }}$ and tubulin acetylation expression levels. Methyl sulfide 15c increased weakly these levels in line with its noticeable effect on the induction of differentiation. While the 11a-g series did not show a significant effect on tubulin acetylation, some members (11b-e) up-regulated p21 WAF1 to levels even higher than those of SAHA. The effect of the analogues on the level of histone acetylation was also analyzed by Western blot (Fig. 3D). After treating U937 cells for $24 \mathrm{~h}$ all compounds of the series 11ag displayed the ability to increase the level of acetylated histone $\mathrm{H} 3$, present in the histonic extract, as shown using the specific antibody.
In order to determine if the most potent analogues are endowed with additional epigenetic modulation activities, the series 11a-g and $\mathbf{2 0}$ were also used in in vitro human SIRT1 fluorescent assay and in a radioactive assay on a peptide fragment having p300/ CBP histone acetyl transferase (HAT) enzyme activity. As shown in Figure 4B, very weak SIRT1 inhibition was noted (ca. 30\% relative to the control) for the majority of compounds at $50 \mu \mathrm{M}$, far lower than the activity of the SIRT1 inhibitor suramin at the same concentration. In addition, none of the analogues displayed modulation of a peptide fragment of CBP containing the enzymatically active HAT domain (Fig. 4A) relative to the control and to the effects of the known inhibitor anacardic acid (AA) at the same concentration, ${ }^{65,66}$ thus confirming the specificity of the HDAC among other epigenetic inhibitory activities.

DNMT inhibition has also been reported for PsA. ${ }^{3}$ To verify the effective physical interaction between PsA and its analogues and DNA methyl transferase enzymes, two in vitro radioactive assays were performed using DNMT1 and DNMT3A (Fig. 4C and D). DNMT1 was immunoprecipitated from K562 cells and used in radioactive assay that employs $\left[{ }^{3} \mathrm{H}\right]$-adenosyl-L-methionine as methyl donor and Poly dI-dC as methyl acceptor. The same conditions have been used for the DNMT3A radioactive assay, but the 
A

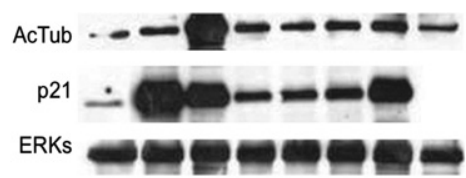

$\begin{array}{lllllllll}\text { C } & \text { MS } & \text { SA } & 13 & 16 & 15 b & 15 c & 21\end{array}$

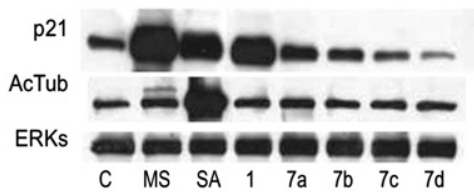

B

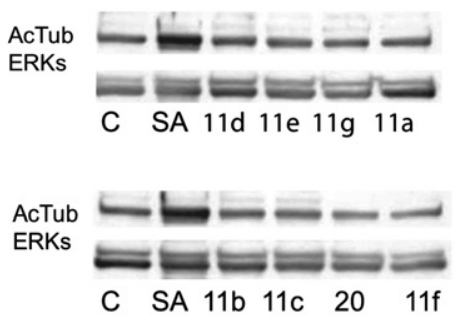

C

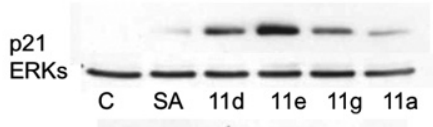

p21

ERKs

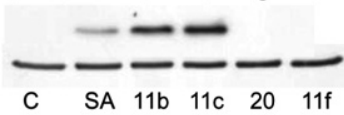

D
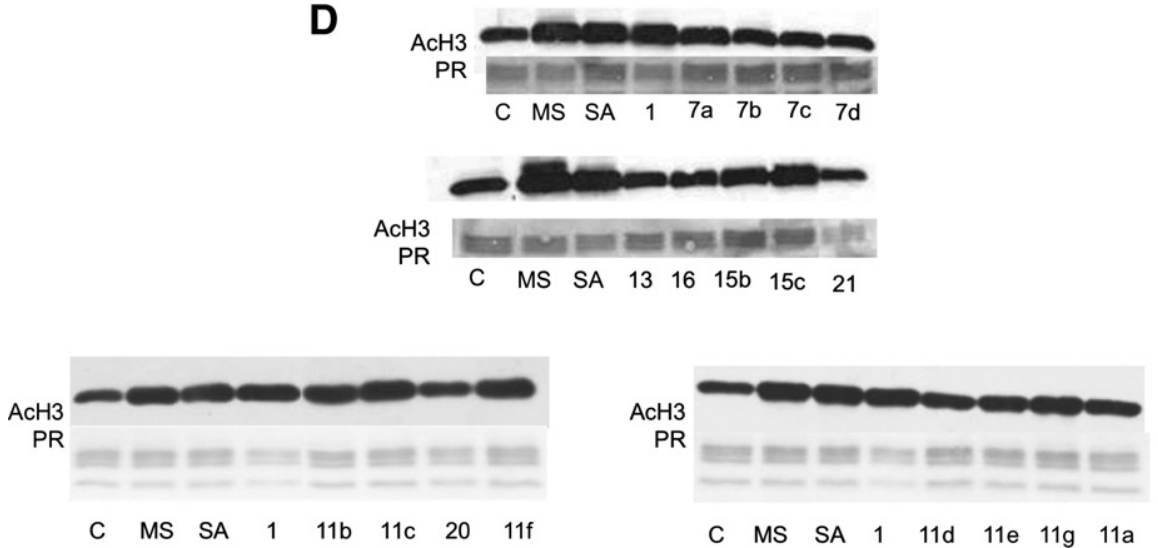

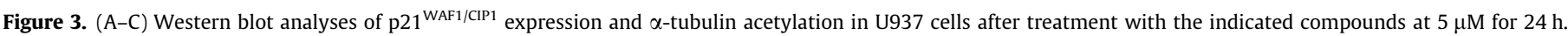

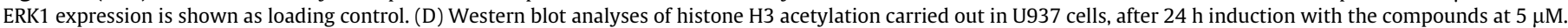

recombinant enzyme was produced in Escherichia coli BL21, as GST fused protein. In neither assay compounds 11a-g and 20 showed significant inhibition at $50 \mu \mathrm{M}$ (see Fig. 4C), in contrast to RG $108^{67}$ and SGI $1027^{68}$ at the same concentration for the DNMT1 assay.

Taken together, the enzymatic profiling suggests that the epigenetic activities of PsA are mainly restricted to the inhibition of the HDAC family in this context. Moreover, the HDAC activity of the series is likely linked to the formation of the monomeric thiol that originates from $-\mathrm{S}$. S S- bond cleavage (Scheme 7, vide infra), a known potent metal chelator. The $\mathrm{Zn}^{2+}$-dependent histone deacetylase subfamily is composed of Class I HDACs (HDAC $1-3,8$ and 11) and Class II HDACs (HDAC 4-7, 9 and 10). In contrast, Class III (sirtuins), with seven members (SIRT1-7), require $\mathrm{NAD}^{+}$as a cofactor and release $O$-acetyl-ADP ribose and nicotinamide as a consequence of acetyl transfer from the acetylated lysine. ${ }^{69}$

Metalloproteinase-targeted HDAC inhibitors are typically substrate mimics of the linear acetyl-lysine side chain with a $\mathrm{Zn}^{2+}$-chelating 'warhead' group that replaces the scissile acetamide, a connector chain and a 'cap' at the other end that extend beyond the enzyme substrate-binding channel. These features are exhibited by the thiol derived from PsA (Scheme 7), in which the active site binding/inactivating group is connected via a hydroxyimino amide linker to the HDAC recognition aryl group.

In order to address the nature of the interaction between the inhibitor and HDAC, the ab initio calculated structure of thiol 22 was docked into the active site of the human HDAC8-trichostatin A (TSA) crystal structure ${ }^{70}$ after removal of the TSA ligand. The catalytic domain of about 390 amino acids responsible for the deacetylation is highly conserved among the metal-dependent HDACs, in particular the residues lining the ligand-binding pocket, but some differences can be exploited for the designed of selective Class I/Class II HDAC inhibitors. ${ }^{71}$

The highest scores using automated docking method for the interaction of the ligand with the $\mathrm{Zn}^{2+}$ ion in the active site, validated by the GRID maps, agree in having the thiol chelated to the metal, whereas the linker domain occupies the channel and the $o$-bromophenol is stabilized through interaction with Tyr100 and Phe152 at the rim of the active site entrance (Fig. 5 and Figs. S1-S3). This positioning facilitates the formation of a hydrogen bond between the oxime group and Asp101, which remains at a constant distance along the energy minimization and the simulation of the dynamic behaviour using unrestrained MD (Fig. S3). The $\mathrm{Zn}^{2+}$ ion is kept firmly coordinated to the four ligands (Asp178, Asp267, His180 and the thiol group of the inhibitor), 
A
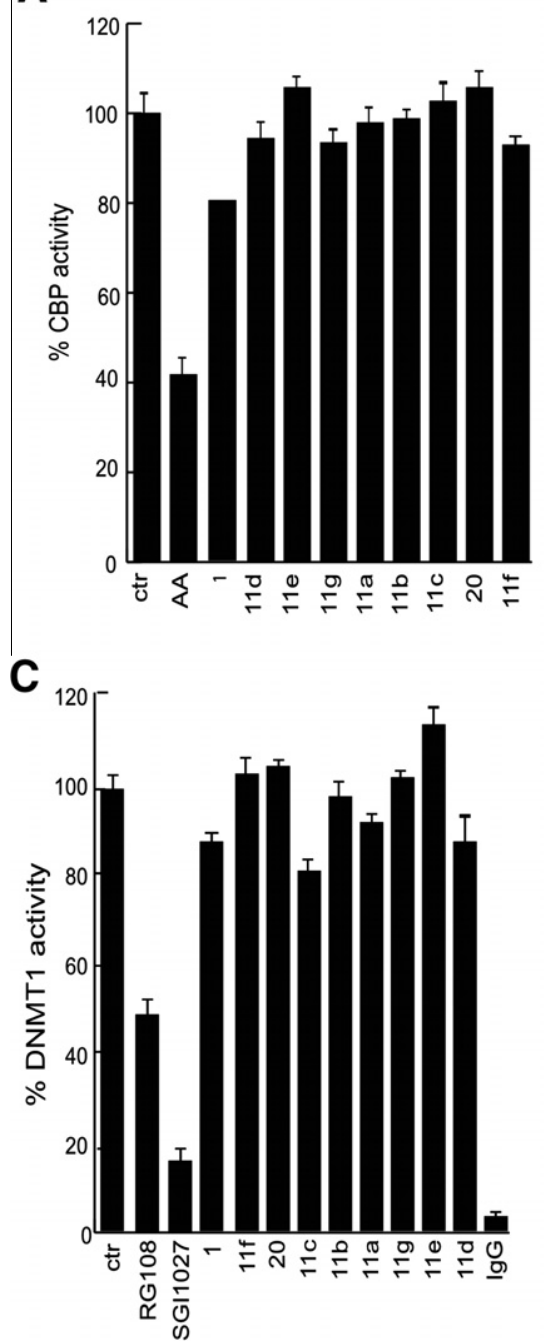

B

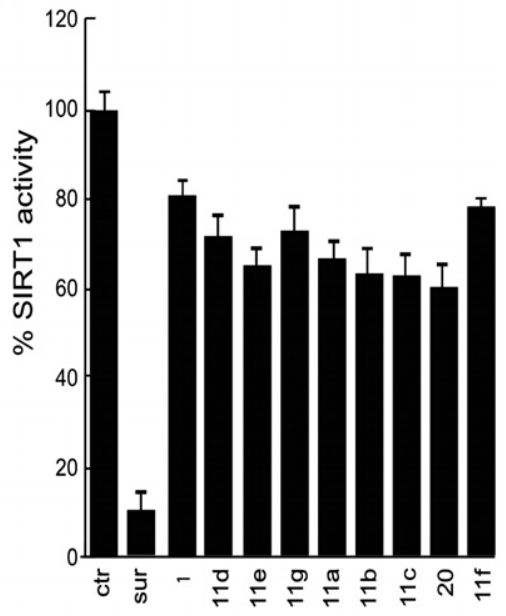

D

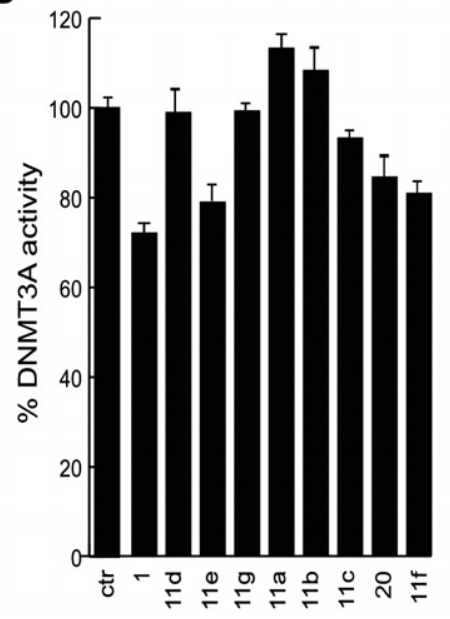

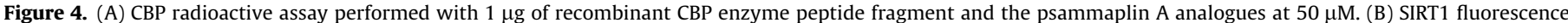

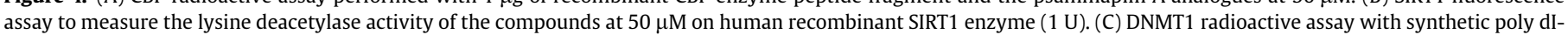

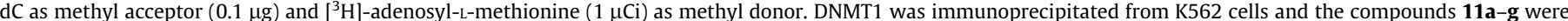

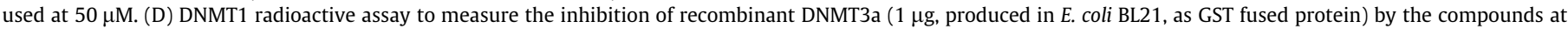
$50 \mu \mathrm{M}$. In each panel the inhibition/activation of the enzyme is reported as percentage of activity relative to the control.

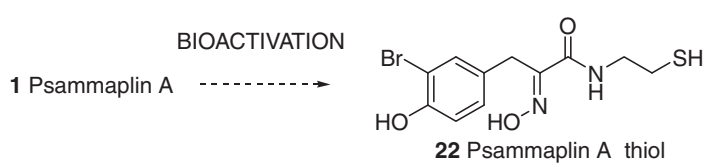

Scheme 7. Bioactivation of PsA $\mathbf{1}$ to thiol 22 by the reductive environment of the cells.

and the electrostatic term $(-59.2191 \pm 1.7841 \mathrm{kcal} / \mathrm{mol})$ makes an important contribution to the overall energy. Favourable van der Waals interactions of the ligand with Phe152 and Phe208 residues also account for a fraction of the intermolecular energy component (Fig. S2).

\section{Discussion}

Psammaplin A $\mathbf{1}$ is the prototype of a collection of metabolites isolated from sponges ${ }^{1}$ that are biosynthesized by linear connections of (bromo)tyrosines and modified cysteines. ${ }^{12}$ Their biological activities, common to most of the bromotyrosine/cysteine constructs, range from antimicrobial ${ }^{54}$ to anticancer. ${ }^{1,6}$ The inhibi- tion of several enzymes that impact different stages on the onset and progression of cancer such as topoisomerase II (growth), ${ }^{14}$ the zinc-dependent metalloproteinase aminopeptidase N (APN, tumor cell invasion or angiogenesis), ${ }^{21}$ HDAC and DNMT (chromatin remodeling), ${ }^{3}$ among others, likely conspire to account for the reported anticancer activities of PsA in several cancer cell lines and in the A549 lung xenograft mouse model. ${ }^{3,12}$ PsA was reported to activate Wnt signalling in a cell-based assay but the effect is likely due to HDAC inhibition rather than to an specific Wnt signalling pathway. ${ }^{72}$

More recent molecular and cellular studies ${ }^{73}$ confirmed the potent inhibitory activity of PsA in enzymatic (HDAC inhibition) and in anti-proliferation assays, and also the selective induction of histone hyperacetylation. The anti-proliferative effects were linked to the overexpression of genes related to cell cycle arrest and apoptosis ( $\mathrm{p} 53$-independent $\mathrm{p} 21^{\mathrm{WAF} 1}$ expression) ${ }^{74}$

A series of PsA analogues modified at the aryl ring, with varying lengths of the amino thiol connecting unit, and some exchanges/ deletions of functional groups have been prepared. These analogues have been characterized with regard to their enzymatic inhibitory potential and for their effects on cell cycle, differentia- 


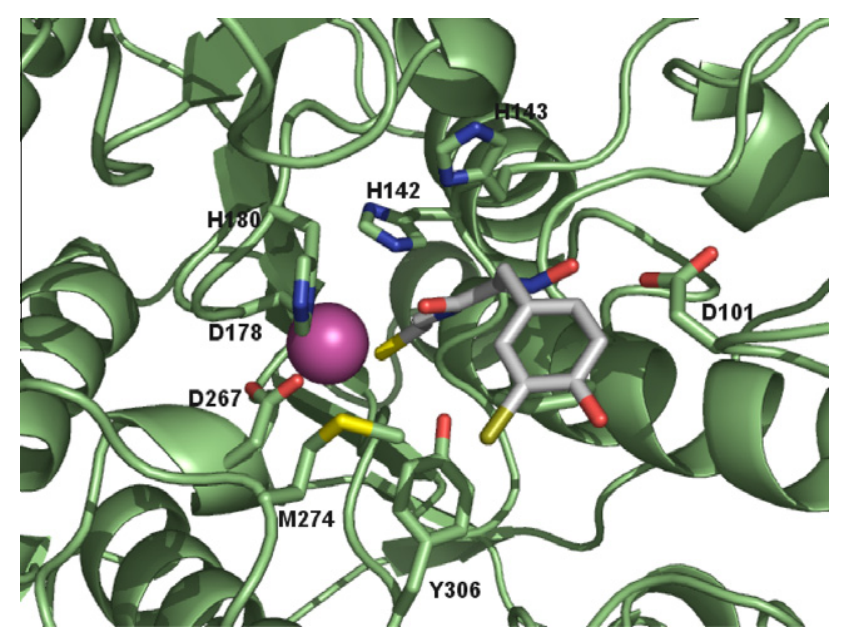

Figure 5. Proposed docking pose of biocleaved psammaplin A (thiol 22) with HDAC8. The $\mathrm{C} \alpha$ trace of the enzyme is displayed as a ribbon, colored in green. The side chains of His142, His143, Asp178, Asp267, His180, Met274, Tyr306 are shown as sticks, with carbon atoms colored in green. The $\mathrm{Zn}^{2+}$ ion at the catalytic site is shown as a magenta sphere. The inhibitor is displayed also as sticks, but with carbon atoms colored in gray and the bromine atom colored in brown.

tion and apoptosis on the U937 acute myeloid leukemia cell line. For $\mathbf{1}$ and the most potent analogues, functional assays have also been carried out on the same cell line.

Enzymatic HDAC1 inhibition data for the series of analogues having chain lengths spanning from two to six methylene units ( 7a-d) established that the derivative of natural cystamine (the decarboxylated cysteine) present in psammaplin A was the most potent, and also that both the oxime and the disulfide functionalities were required for the HDAC inhibition activity, since analogues 13, 15b-c, 16 and 20 proved to be inactive (Fig. 1A). We then addressed the modifications of the aryl ring with analogues that preserve the same connecting diamine unit of the parent natural product. The substitution at the ring is well tolerated, and a general improvement in potency relative to PsA was noted when the ring was mono- $(\mathbf{1 1 a}-\mathbf{b})$ or disubstituted $(\mathbf{1 1 d}, \mathbf{e}, \mathbf{g})$. The unsubstituted compound (the phenylalanine-derived 11c) and the trisubstituted bromopsammaplin A 11f were less active than $\mathbf{1 .}$ Conversely the series of halogenated analogues 11d,e,g exhibited greater potency than PsA and followed the order $\mathrm{Br}<\mathrm{F}<\mathrm{Cl}<\mathrm{I}$. The activities of the spiro derivative $\mathbf{2 1}$ are most intriguing, since it is the only compound showing a G2/M block (Fig. 1B) and strong induction of apoptosis (Fig. 2B), which appears not to be correlated with HDAC inhibition. A promising pro-differentiation profile is also noted for the methylsulfide 15c (Fig. 2B), which merit further investigation.

It has previously been reported that human endometrial Ishikawa cancer cells treated with PsA showed accumulation of cells in the G1 phase and a significant decrease in the number of cells in the $\mathrm{S}$ phase, ${ }^{74}$ a result in keeping with the effect of known HDAC inhibitors. ${ }^{75}$ Our data confirm the time-dependent accumulation of cells in G1 upon treatment of human leukaemia U937 cells with PsA and analogues. Moreover, 1 and the $\mathbf{1 1 a - g}$ series of related compounds induced apoptosis of U937 cells (Fig. 2B), an effect likely associated to their more selective inhibition of class I HDACs. The majority of these compounds (with the exception of 15c) failed to induce tubulin acetylation (Fig. 3), which is a target of HDAC6 enzymes, and this finding is in agreement with previous reports for PsA in HeLa cells. ${ }^{73}$ Although the result might suggest that psammaplin A show selectivity for histone proteins in preference to tubulin, it cannot be considered as a selective class I HDAC inhibitor, since it also inhibits HDAC4, a class II HDAC, in enzymatic assays (results not shown). Important differences between class I and class II metalo-HDACs are noticeable in their size (with class II being from two to three times larger), their cellular localization, the conservation of sequence motifs in the catalytic domains, the identity of the protein-protein interaction complexes and the tissue distribution. ${ }^{76}$

Western blot analysis of U937-treated cells confirmed the accumulation of acetylated histones using antibodies against acetylated H3 (Fig. 3D), in agreement with similar findings for PsA in endometrial cancer Ishikawa cells. ${ }^{74}$ PsA and several analogues up-regulated cyclin-dependent kinase inhibitor p2 ${ }^{\text {WAF1 }}$ (Fig. 3), which is one of the genes induced by HDAC inhibitors, ${ }^{76}$ and this effect might be related to the suppression of cell proliferation and induction of apoptosis.

PsA and its 5-bromo derivative have been reported to inhibit the bacterial methyltransferase SssI. However, cultured HCT116 human colon carcinoma cells treated with $1 \mu \mathrm{M}$ PsA did not reduce global genomic DNA methylation (the level of which was determined using a mass spectrometry assay) and failed to induce the hypomethylation or reactivation of cancer-testis antigen genes, known as methylation silenced genes. ${ }^{56}$ Here, two different assays were performed on DNMT1 and DNMT3A (see Fig. 4C and D) to evaluate the inhibition of DNMT enzymes by PsA and derivatives (11a-g). Differently from expected, these compounds at $50 \mu \mathrm{M}$ failed to inhibit DNMT1 and DNMT3a, thus indicating their inability to alter DNMT in vitro. Therefore, the action of these compounds on cell cycle progression and induction of apoptosis can be better correlated with the HDAC inhibitory activities. It is likely that the absence of hypomethylation is not due to the low affinity of PsA (and its analogues) for DNMT, but instead to the inefficient transport of these compounds through the nuclear membrane. Inefficient transportation of the compound into the nucleus or poor cell membrane penetration might also explain the much greater concentration of 1 (1800 times) required to obtain similar potencies in cell-based assays relative to the HDAC enzymatic inhibition assay. $^{52}$

Lastly, no significant inhibition of SIRT1 and p300/CBP HAT enzymes was seen for the PsA-related series of analogues (Fig. 4A and $\mathrm{B}$ ).

Other natural products of the depsipeptide class that act as inhibitors of HDAC also contain disulfide bonds, namely FK228 23, spiruchostatins 25 and FR901375 26 (Fig. 6). ${ }^{39,71}$ FK228 (romi-

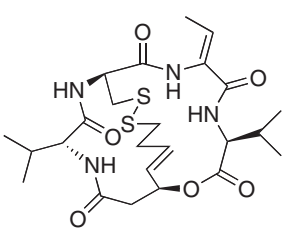

23, FK228 (FR901228)
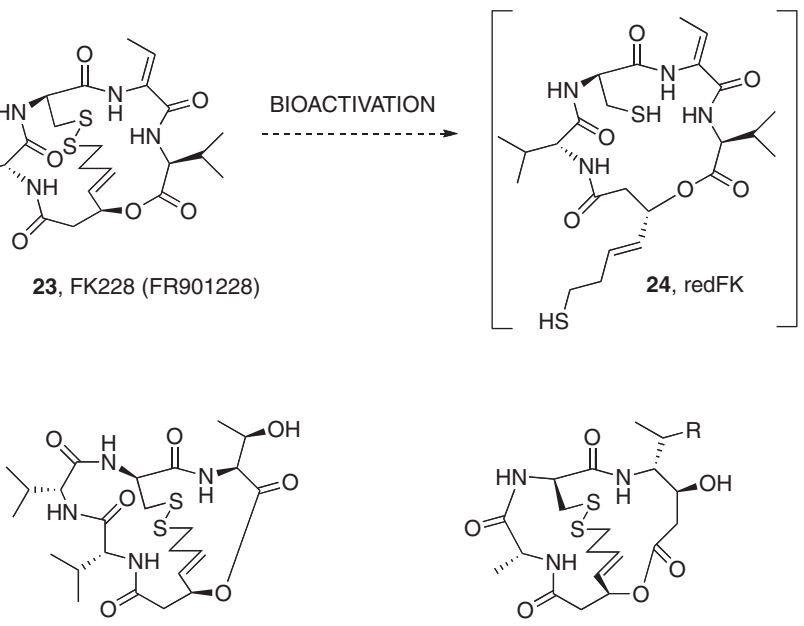

25, FR901375

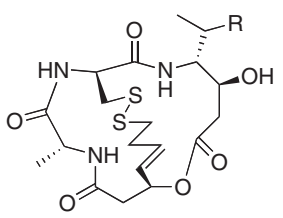

26a, Spiruchostatin A R = Me 26b, Spiruchostatin B R = H
Figure 6. Natural depsipeptides 23-26 containing disulfide bonds are HDAC inhibitors. The structure of previously characterized active reduced form of FK228 (24, redFK) is shown by analogy with the reduced form of psammaplin A, 22. 
depsin, Istodax ${ }^{\circledR}$ ) currently approved for T cell lymphoma is undergoing phase II clinical trials for the treatment of non-Hodgkin's lymphoma, acute myelogeneous leukemia, and pancreatic cancer (www.clinicaltrials.gov). It has been shown that the disulfide bond of FK228 becomes cleaved in the cells by the reducing activity of glutathione to afford redFK 24, and the thiol then interacts with the $\mathrm{Zn}^{2+}$ ion in the active site of HDAC. ${ }^{77}$ Moreover, mass spectrometry analysis of blood samples identified the thiol and glutathione conjugates of FK228. ${ }^{78}$ Upon bio-reduction depsipeptides 25 and 26 must also release the $\mathrm{Zn}^{2+}$-binding butenylthiol. ${ }^{79}$ From an structural point of view both redFK 25 and PsA thiol 22 have $\mathrm{Zn}^{2+}$ ion connecting chains that are shorter than those of common hydroxamic acid-based inhibitors (TSA, SAHA...). Thiol chelating groups connected via a 5 atom saturated chain to cyclic tetrapeptides have also shown potent HDAC inhibitory activities. ${ }^{80,81}$

In agreement with these precedents, the dimer analogue lacking the disulfide bond (13) was inactive, which substantiates the proposal that PsA and analogues undergo thiolate exchange reaction with glutathione by -S...S- bond cleavage. ${ }^{82}$ Interestingly, Wang et al. have shown that glutathione-depleted cells were not sensitive to PsA, implying that the reducing environment of the cells triggered the conversion of the disulfide of $\mathbf{1}$ to the corresponding thiol, ${ }^{79}$ which would be the species responsible for the HDAC inhibitory activity of psammaplin A after uptake into the cells.

Based on the reported crystal structure, the HDAC $8 \cdot \mathrm{Zn}^{2+}$.thiol 22 complex was constructed with the thiol group chelating the metal ion, and then refined using energy minimization. The dynamic behaviour of the complex using unrestrained molecular dynamics confirmed the feasibility of the proposed binding orientation and the mutual adaptation between HDAC8 and the ligand. The linker occupies the narrow channel whereas the bromophenol interacts with Tyr100 and Phe152 at the rim of the active site entrance, a pose that facilitates the formation of a robust hydrogen bond between the oxime group and Asp101 (Fig. 5).

Our results using alcohol 16, ether 15b and most importantly dimer 13 confirm the earlier findings with FK228 ${ }^{78}$ and suggest that psammaplin A $\mathbf{1}$ acts as a stable pro-drug ${ }^{83}$ that is activated upon uptake by the reductive environment of the cells to afford thiol 22, which then chelates the $\mathrm{Zn}^{2+}$ ion in the active site of the HDAC metalloenzymes.

\section{Conclusion}

PsA 1, a natural product with a disulfide bond derived from the condensation of modified cystamine and tyrosine moieties, has been reported to display dual HDAC and DNMT epigenetic inhibitory activities. The intriguing ability to target simultaneously more than one member of the epigenetic machinery (epigenetic multiple ligands), ${ }^{84}$ prompted us to synthesize a series of PsA analogues in an effort to determine the structural determinants for their epigenetic profile. We have analyzed the effects of the natural-product inspired collection on the human leukaemia U937 cell cycle, measuring induction of apoptosis and differentiation, induction of p21 WAF1 and tubulin acetylation levels and total histone $\mathrm{H} 3$, and also examined their HDAC1 enzyme-based inhibition profile. From the results it is concluded that Nature has optimized the design of the PsA scaffold to fulfil this epigenetic role, since only closely related synthetic derivatives (with modifications at the bromotyrosine ring) exhibited comparable or greater potency than the natural product. Modifications of the connecting chain, oxime bond and disulfide unit afforded either inactive or considerable less potent analogues. Exploring the possibility that PsA and derivatives might display additional epigenetic activities we have also tested them as inhibitors of DNMT1, DNMT3A, SIRT1 and a peptide containing the $\mathrm{p} 300 / \mathrm{CBP}$ HAT domain, but the values measured were very low. Since epigenetic signalling by PsA appears to be restricted to inhibition of metalloproteinase HDACs, a model for the interaction of HDAC8 with the thiol derived from PsA 1 (by a presumed in vivo disulfide cleavage) was computed. The thiol binds the $\mathrm{Zn}^{2+}$ ion in the active site and the complex is additionally stabilized by a hydrogen bond interaction between the oxime group and the Asp101 residue located at the active site entrance. As with FK228, this bioactivation mechanism illustrates the ingenious solution adopted by Nature to protect the reactive zinc-binding thiol as a disulfide pro-drug with higher bioavailability. The increased levels of disulfide reductants (i.e., glutathione, thioredoxin and thioredoxin reductase) found in many cancer cells render such cells particularly susceptible to the action of PsA 1.

Despite the failure to greatly improve the epigenetic inhibitory profile of PsA through the modifications reported, more significant skeletal alterations of the PsA structure might provide more potent derivatives, thus lending further support to the important role of natural products as inspiration ${ }^{85}$ for the development of designed multiple ligands ${ }^{50,51}$ as new anticancer drugs. ${ }^{86,87}$

\section{Experimental section}

\subsection{General}

Solvents were dried according to published methods and distilled before use. HPLC grade solvents were used for the HPLC purification. All other reagents were commercial compounds of the highest purity available. All reactions were carried out under argon atmosphere, and those not involving aqueous reagents were carried out in oven-dried glassware. Analytical thin layer chromatography (TLC) was performed on aluminium plates with Merck Kieselgel 60F254 and visualized by UV irradiation $(254 \mathrm{~nm})$ or by staining with a solution of phosphomolibdic acid. Flash column chromatography was carried out using Merck Kieselgel 60 (230400 mesh) under pressure. Infrared spectra were obtained on JASCO FTIR 4200 spectrophotometer, from a thin film deposited onto a $\mathrm{NaCl}$ glass. ${ }^{1} \mathrm{H}$ NMR spectra were recorded in $\mathrm{CDCl}_{3}, \mathrm{CD}_{3} \mathrm{OD}$, DMSO$d_{6}$ and $\left(\mathrm{CD}_{3}\right)_{2} \mathrm{CO}$ at ambient temperature on a Bruker AMX-400 spectrometer at $400 \mathrm{MHz}$ with residual protic solvent as the internal reference $\left(\mathrm{CDCl}_{3}, \delta_{\mathrm{H}}=7.26 \mathrm{ppm} ;\left(\mathrm{CD}_{3}\right)_{2} \mathrm{CO}, \delta_{\mathrm{H}}=2.05 \mathrm{ppm}\right.$; $\mathrm{CD}_{3} \mathrm{OD}, \delta_{\mathrm{H}}=3.31 \mathrm{ppm}$; DMSO- $\left.d_{6}, \delta_{\mathrm{H}}=2.50 \mathrm{ppm}\right)$; chemical shifts $(\delta)$ are given in parts per million (ppm), and coupling constants $(J)$ are given in Hertz $(\mathrm{Hz})$. The proton spectra are reported as follows: $\delta$ (multiplicity, coupling constant $J$, number of protons, assignment). ${ }^{13} \mathrm{C}$ NMR spectra were recorded in $\mathrm{CDCl}_{3} \mathrm{CD}_{3} \mathrm{OD}$, DMSO- $d_{6}$ and $\left(\mathrm{CD}_{3}\right)_{2} \mathrm{CO}$ at ambient temperature on the same spectrometer at $100 \mathrm{MHz}$, with the central peak of $\mathrm{CDCl}_{3}$ $\left(\delta_{\mathrm{C}}=77.0 \mathrm{ppm}\right), \mathrm{CD}_{3} \mathrm{OD}\left(\delta_{\mathrm{C}}=49.0 \mathrm{ppm}\right), \mathrm{DMSO}-d_{6}\left(\delta_{\mathrm{C}}=39.4 \mathrm{ppm}\right)$ or $\left(\mathrm{CD}_{3}\right)_{2} \mathrm{CO}\left(\delta_{\mathrm{C}}=30.8 \mathrm{ppm}\right)$ as the internal reference. The DEPT135 sequence was used to aid in the assignment of signals on the ${ }^{13} \mathrm{C}$ NMR spectra. Melting points were determined on a Stuart SMP10 apparatus. Elemental analyses were determined on a Carlo Erba EA 1108 analyzer. MS experiments were performed on an APEX III FT-ICR MS (Bruker Daltonics, Billerica, MA), equipped with a 7T actively shielded magnet. Ions were generated using an Apollo API electrospray ionization (ESI) source (Bruker Daltonics, Billerica, MA), with a voltage between 1800 and $2200 \mathrm{~V}$ (to optimize ionisation efficiency) applied to the needle, and a counter voltage of $450 \mathrm{~V}$ applied to the capillary. Samples were prepared by adding a spray solution of 70:29.9:0.1 (v/v/v) methanol/water/formic acid to a solution of the sample at a $\mathrm{v} / \mathrm{v}$ ratio of $1-5 \%$ to give the best signal-to-noise ratio. Data acquisition and data processing were performed using the XMASS software, version 6.1.2 (Bruker Daltonics). FAB experiments were performed on a VG AutoSpec instrument, using 3-nitrobenzylalcohol or glycerol as matrix. 


\subsection{General procedure for the oxidation of amines with $\mathrm{Na}_{2} \mathrm{WO}_{4}$}

To a solution of amine $(18.0 \mathrm{mmol})$ in EtOH $(40 \mathrm{~mL})$ at $0{ }^{\circ} \mathrm{C}$ were added $\mathrm{Na}_{2} \mathrm{WO}_{4} \cdot 2 \mathrm{H}_{2} \mathrm{O}(18 \mathrm{mmol}), 30 \% \mathrm{H}_{2} \mathrm{O}_{2}(16 \mathrm{~mL})$ and $\mathrm{H}_{2} \mathrm{O}$ $(30 \mathrm{~mL})$. The resulting mixture was stirred for $4 \mathrm{~h}$ at room temperature and the reaction was quenched with aqueous saturated $\mathrm{NH}_{4} \mathrm{Cl}$ and extracted with EtOAc $(3 \times)$. The combined organic extracts were washed with brine, dried over $\mathrm{Na}_{2} \mathrm{SO}_{4}$ and evaporated. The residue was purified by column chromatography on silica gel as indicated.

\subsection{General procedure for the hydrolysis of esters}

Lithium hydroxide ( $15 \mathrm{mmol}$ ) was added to a solution of ester $(1 \mathrm{mmol})$ in a $1: 1 \mathrm{THF} / \mathrm{H}_{2} \mathrm{O}(16 \mathrm{~mL})$ mixture. The solution was stirred at room temperature for $2 \mathrm{~h}$, neutralized with $10 \% \mathrm{HCl}$ and extracted with EtOAc $(4 \times)$. The combined organic layers were washed with brine, dried over $\mathrm{Na}_{2} \mathrm{SO}_{4}$, filtered and the solvent was evaporated in vacuo. Crystallization of the residue provided the desired acid as indicated.

\subsection{General procedure for the amidation of tyrosine acid derivatives with amines}

$\mathrm{N}$-Hydroxyphtalimide ( $1 \mathrm{mmol})$ and DCC ( $1 \mathrm{mmol})$ were added to a solution of the carboxylic acid $(1 \mathrm{mmol})$ in dioxane $(2.5 \mathrm{~mL})$. After the mixture had been stirred for $2 \mathrm{~h}$ at room temperature, a solution of the amine $(0.5 \mathrm{mmol}), \mathrm{Et}_{3} \mathrm{~N}(2 \mathrm{mmol})$ and $\mathrm{MeOH}$ $(1 \mathrm{~mL})$ was added. The resulting mixture was stirred for $12 \mathrm{~h}$ at room temperature and the reaction was quenched with $\mathrm{H}_{2} \mathrm{O}$ and extracted with EtOAc $(3 \times)$. The combined organic extracts were washed with brine, dried over $\mathrm{Na}_{2} \mathrm{SO}_{4}$ and evaporated. The residue was dissolved in THF, filtered off and the solvent was evaporated in vacuo. The resulting residue was then purified by column chromatography on silica gel as indicated.

\subsection{1. (E)-Methyl 2-(hydroxyimino)-3-(4- hydroxyphenyl)propanoate $(3)^{88}$}

Following the general procedure for the oxidation of amines with $\mathrm{Na}_{2} \mathrm{WO}_{4} \cdot 2 \mathrm{H}_{2} \mathrm{O}$, L-tyrosine methyl ester 2 ( $3.45 \mathrm{~g}, 17.68 \mathrm{mmol}$ ) gave, after purification by column chromatography $\left(\mathrm{SiO}_{2}, 50: 50\right.$ hexane/EtOAc), $2.24 \mathrm{~g}(60 \%)$ of oxime 3 as a white powder. ${ }^{1} \mathrm{H}$ NMR $\left(\mathrm{CD}_{3} \mathrm{COCD}_{3}, 400.13 \mathrm{MHz}\right): \delta 11.35(\mathrm{~s}, 1 \mathrm{H}, \mathrm{OH}), 8.11(\mathrm{~s}, 1 \mathrm{H}$, $\mathrm{OH}), 7.11(\mathrm{~d}, J=8.5 \mathrm{~Hz}, 2 \mathrm{H}, \mathrm{ArH}), 6.73(\mathrm{~d}, J=8.5 \mathrm{~Hz}, 2 \mathrm{H}, \mathrm{ArH})$, $3.84(\mathrm{~s}, 2 \mathrm{H}, 2 \mathrm{H} 3), 3.72\left(\mathrm{~s}, 3 \mathrm{H}, \mathrm{CO}_{2} \mathrm{CH}_{3}\right) \mathrm{ppm}$.

\subsection{2. (E)-Methyl 3-(3-bromo-4-hydroxyphenyl)-2- (hydroxyimino)propanoate $(4)^{61}$}

A solution of NBS $(0.49 \mathrm{~g}, 2.75 \mathrm{mmol})$ in $\mathrm{CH}_{3} \mathrm{CN}(6 \mathrm{~mL})$ was added dropwise over $15 \mathrm{~min}$ to the solution of the oxime 3 $(0.58 \mathrm{~g}, 2.75 \mathrm{mmol})$ in $\mathrm{CH}_{3} \mathrm{CN}(6 \mathrm{~mL})$. The reaction mixture was stirred at room temperature for $5 \mathrm{~h}$, after which time the solvent was evaporated and the residue was treated with water and extracted with EtOAc $(3 \times)$. The combined organic extracts were dried over $\mathrm{Na}_{2} \mathrm{SO}_{4}$, filtered, evaporated and the residue was purified by column chromatography $\left(\mathrm{SiO}_{2}, 50: 50\right.$ hexane/EtOAc) to afford oxime $4(0.65 \mathrm{~g}, 82 \%)$ as a yellow powder. ${ }^{1} \mathrm{H}$ NMR $\left(\mathrm{CD}_{3} \mathrm{COCD}_{3}, 400.13 \mathrm{MHz}\right): \delta 11.49(\mathrm{~s}, 1 \mathrm{H}, \mathrm{OH}), 8.62(\mathrm{~s}, 1 \mathrm{H}, \mathrm{OH})$, 7.44 (d, $\left.J=1.6 \mathrm{~Hz}, 1 \mathrm{H}, \mathrm{H2} 2^{\prime}\right), 7.13$ (dd, $\left.J=8.3,1.6 \mathrm{~Hz}, 1 \mathrm{H}, \mathrm{H}^{\prime}\right), 6.90$ (d, $J=8.3 \mathrm{~Hz}, 1 \mathrm{H}, \mathrm{H}^{\prime}$ ), 3.85 (s, 2H, 2H3), 3.74 (s, 3H, $\left.\mathrm{CO}_{2} \mathrm{CH}_{3}\right) \mathrm{ppm}$.

\subsection{3. (E)-3-(3-Bromo-4-hydroxyphenyl)-2- (hydroxyimino)propanoic Acid (5)}

In accordance with the general procedure for the hydrolysis of esters, ester $4(0.61 \mathrm{~g}, 2.11 \mathrm{mmol})$ gave, after purification by column chromatography $\left(\mathrm{SiO}_{2}, 90: 10 \mathrm{EtOAc} / \mathrm{MeOH}\right), 0.58 \mathrm{~g}$ (99\%) of acid 5 as a white powder, mp: $147-148{ }^{\circ} \mathrm{C}$ (hexane $/ \mathrm{CHCl}_{3}$ ) (lit. 147-148 ${ }^{\circ} \mathrm{C}$, dec.). ${ }^{89}{ }^{1} \mathrm{H} \mathrm{NMR}\left(\mathrm{CD}_{3} \mathrm{COCD}_{3}, 400.13 \mathrm{MHz}\right): \delta 7.45$ (s, $\left.1 \mathrm{H}, \mathrm{H}^{\prime}\right), 7.14(\mathrm{~d}, J=7.9 \mathrm{~Hz}, 1 \mathrm{H}, \mathrm{ArH}), 6.90(\mathrm{~d}, J=7.9 \mathrm{~Hz}, 1 \mathrm{H}, \mathrm{ArH})$, $3.84(\mathrm{~s}, 2 \mathrm{H}, 2 \mathrm{H} 3) \mathrm{ppm}$.

6.4.4. (2E,2'E)- $N, N^{\prime}-\left[2,2^{\prime}\right.$-Disulfanediylbis(ethane-2,1-diyl)]bis[3(3-bromo-4-hydroxyphenyl)-2-(hydroxyimino)propanamide] (psammaplin A, 1) ${ }^{56}$

Following the general procedure for the amidation of tyrosine acid derivatives with amines, acid $5(0.16 \mathrm{~g}, 0.59 \mathrm{mmol})$ afforded after purification by column chromatography $\left(\mathrm{SiO}_{2}\right.$, gradient from 25:75 hexane/EtOAc to $\left.95: 5 \mathrm{CH}_{2} \mathrm{Cl}_{2} / \mathrm{MeOH}\right)$, psammaplin A 1 $(0.12 \mathrm{~g}, 60 \%)$ as a white foam. ${ }^{1} \mathrm{H} \mathrm{NMR}\left(\mathrm{CD}_{3} \mathrm{OD}, 400.13 \mathrm{MHz}\right)$ (data for monomer): $\delta 7.36$ (s, $\left.1 \mathrm{H}, \mathrm{H2}{ }^{\prime}\right), 7.07(\mathrm{~d}, J=8.3 \mathrm{~Hz}, 1 \mathrm{H}, \mathrm{ArH}), 6.76$ (d, $J=8.3 \mathrm{~Hz}, 1 \mathrm{H}, \mathrm{ArH}), 3.79(\mathrm{~s}, 2 \mathrm{H}, 2 \mathrm{H} 3), 3.52$ (t, $J=6.7 \mathrm{~Hz}, 2 \mathrm{H}$, $\left.2 \mathrm{H}^{\prime \prime}\right), 2.81\left(\mathrm{t}, J=6.7 \mathrm{~Hz}, 2 \mathrm{H}, 2 \mathrm{H} 2^{\prime \prime}\right), 2.15(\mathrm{br}, 2 \mathrm{H}, \mathrm{OH}) \mathrm{ppm}$.

\subsection{Molecular modeling of psammaplin A}

\subsubsection{Quantum mechanics calculations}

The geometry of the thiol derived from psammaplin A was optimized using the ab initio quantum chemistry program Gaussian $03^{90}$ and the HF/3-21G* basis set. A set of atom-centred RHF 6$31 \mathrm{G}^{*} / / 3-21 \mathrm{G}^{*}$ charges was then obtained by using the RESP methodology $^{91}$ as implemented in the AMBER suite of programs (http:// amber.scripps.edu/). Covalent and nonbonded parameters for the inhibitor atoms were assigned, by analogy or through interpolation, from those already present in the AMBER force field ${ }^{92}$ (parm99) or consistently derived, as explained in more detail elsewhere. $^{93}$

\subsubsection{Molecular docking}

The genetic algorithm ${ }^{94}$ implemented in AutoDock ${ }^{95}$ and the h-HDAC8 (PDB code $1 \mathrm{t} 64)^{70}$ as the target protein upon removal of trichostatin A was used to generate different HDAC- $\mathrm{Zn}^{2+}$-bound psammaplin A thiol conformers by randomly changing torsion angles and overall orientation of the molecule. A volume for exploration was defined in the shape of a three-dimensional cubic grid with a spacing of $0.3 \AA$ that enclosed the residues that are known to make up the inhibitors binding pocket. At each grid point, the receptor's atomic affinity potentials for carbon, oxygen, nitrogen, sulfur, bromine and hydrogen atoms present in the ligand were precalculated for rapid intra- and intermolecular energy evaluation of the docking solution.

To obtain additional validation of the proposed binding mode for the ligands, the program GRID (http://www.moldiscovery. $\mathrm{com} /{ }^{96}$ was also used to search for sites on the enzyme that could be complementary to the functional groups present in this inhibitor. For the GRID calculations, a $18 \times 21 \times 21 \AA$ lattice of points spaced at $0.5 \AA$ A was established at the binding site. The probes used were $\mathrm{C} 1$ = (aromatic carbon), $\mathrm{N} 1$ (neutral flat $\mathrm{NH}$, eg amide), $\mathrm{N}$ :\# (sp nitrogen with lone pair), $\mathrm{O}$ (sp2 carbonyl oxygen) and $\mathrm{Br}$ (bromine). The dielectric constants chosen were 4.0 for the macromolecule and 80.0 for the bulk water.

\subsubsection{Molecular dynamics simulations}

Ternary complexes (HDAC8- $\mathrm{Zn}^{2+}$-psammaplin A thiol) representative of the most populated solutions were then refined using the second generation AMBER force field and 3000 steps of steepest descent energy minimization and 6000 steps of conjugate gradient of only the side chain of the protein and those atoms of the bound ligand. This procedure allowed readjustment of covalent bonds and van der Waals contacts without changing the overall conformation of the complex. The HDAC-psammaplin A thiol complex was then neutralized by addition of eight sodium ions ${ }^{97}$ that were placed in electrostatically favored positions and immersed 
in rectangular boxes each containing about 450 TIP3P water molecules $^{98}$ that extended $1 \AA$ away from any solute atom. The cutoff distance for the non-bonded interactions was $9 \AA$, and periodic boundary conditions were applied. Electrostatic interactions were represented using the smooth particle mesh Ewald method with a grid spacing of $\sim 1 \AA$. Unrestrained molecular dynamics (MD) simulations at $300 \mathrm{~K}$ and $1 \mathrm{~atm}$ were then run for $6 \mathrm{~ns}$ using the SANDER module in AMBER $8 .{ }^{99}$ The coupling constants for the temperature and pressure baths were 1.0 and $0.2 \mathrm{ps}$, respectively. SHAKE $^{100}$ was applied to all bonds involving hydrogens, and an integration step of $2 \mathrm{fs}$ was used throughout. The nonbonded pair list was updated every 10 steps. The simulation protocol involving a series of progressive energy minimizations followed by a $20 \mathrm{ps}$ heating phase and a 70 ps equilibration period before data collection. System coordinates were saved every 2 ps for further analysis.

\subsubsection{Analysis of the molecular dynamics trajectories}

Three-dimensional structures and trajectories were visually inspected using the computer graphics program InsightII. The rootmean-square (rms) deviations from both the initial structures and the average structures, the inter-atomic distances, and the snapshot geometries were obtained using the PTRAJ module in AMBER. Intermolecular van der Waals energies for individual residues were calculated with the ANAL module, whereas the solventcorrected residue-based electrostatic interaction energies were calculated with DelPhi, following the procedure described. ${ }^{93}$

All calculations were performed on the SGI R14000 Origin 3800 at CIEMAT (Madrid), on the SGI $1.5 \mathrm{GHz}$ Itanium2 at CESGA (Santiago de Compostela) and locally on SGI R12000 Octane workstations.

\subsection{Biological assays}

\subsubsection{Cell culture}

Human leukaemia cell lines U937, K562 and HL60 were propagated in RPMI medium supplemented with 10\% FBS (Foetal bovine serum; Hyclone) and antibiotics $(100 \mathrm{U} / \mathrm{mL}$ penicillin, $100 \mu \mathrm{g} / \mathrm{mL}$ streptomycin and $250 \mathrm{ng} / \mathrm{mL}$ amphotericin-B). Cells were kept at the constant concentration of 200,000 cells per $\mathrm{mL}$ of culture medium.

\subsubsection{Ligands and materials}

SAHA (Merck) and MS-275 (a kind gift of Bayer-Schering AG) were dissolved in DMSO and used at $5 \times 10^{-6} \mathrm{M}$. All other compounds described were dissolved in DMSO (Sigma-Aldrich) and used at 5 and $50 \mu \mathrm{M}$.

\subsubsection{Cell cycle analysis}

$2.5 \times 10^{5}$ cells were collected and resuspended in $500 \mu \mathrm{L}$ of hypotonic buffer $(0.1 \%$ Triton X-100, $0.1 \%$ sodium citrate, $50 \mu \mathrm{g} /$ $\mathrm{mL}$ propidium iodide, RNAse A). Cells were incubated in the dark for $30 \mathrm{~min}$. Samples were acquired on a FACS-Calibur flow cytometer using the Cell Quest software (Becton Dickinson) and analysed with standard procedures using the Cell Quest software (Becton Dickinson) and the ModFit LT version 3 Software (Verity) as previously reported. ${ }^{101,102}$ Apoptosis was revealed by monitoring nuclear fragmentation (the so-called 'sub-G1 DNA peak') by FACS and analysed by Cell Quest technology.

\subsection{Caspase 3 activation assay}

Caspase activity was detected in living U937 cells using the BIOMOL and B-BRIDGE Kits supplied with cell-permeable fluorescent substrates. The fluorescent substrate for caspase 3 was FAMDEVD-FMK. ca. $1 \times 10^{6}$ cells were washed twice in cold PBS and incubated for $1 \mathrm{~h}$ in ice with the corresponding substrates as rec- ommended by the suppliers. The cells were analysed after washing using the CellQuest software applied to a FACScalibur (BD). Experiments were performed in duplicate and values were expressed as mean \pm SD.

\subsubsection{Granulocyte differentiation}

Granulocyte differentiation was carried out as previously described. ${ }^{103}$ Briefly, U937 cells were harvested and resuspended in $10 \mu \mathrm{L}$ phycoerythrin-conjugated CD11c (CD11c-PE). Control samples were incubated with $10 \mu \mathrm{L}$ PE conjugated mouse IgG1 for $30 \mathrm{~min}$ at $4{ }^{\circ} \mathrm{C}$ in the dark, washed in PBS and resuspended in $500 \mu \mathrm{L}$ PBS containing propidium iodide $(0.25 \mu \mathrm{g} / \mathrm{mL})$. Samples were analyzed by FACS with Cell Quest technology (Becton Dickinson). Propidium iodide (PI) positive cells have been excluded from the analysis.

\subsubsection{Western blot analyses}

Western blot analyses were performed according to standard procedures following suggestions of antibody suppliers. For the determination of $\mathrm{p} 21^{\mathrm{WAF} 1 / \mathrm{CIP} 1} 50 \mu \mathrm{g}$ of total protein extracts were separated on a $15 \%$ polyacrylamide gels and blotted. Western blots were shown for p21 (Transduction Laboratories, dilution 1:500) and total ERKs (Santa Cruz) were used to normalize for equal loading. For $\alpha$-Tubulin acetylation $25 \mu \mathrm{g}$ of total protein extracts were separated on a $10 \%$ polyacrylamide gels and blotted. Western blots where shown for acetylated $\alpha$-tubulin (Sigma, dilution 1:500) and total ERKs (Santa Cruz) or total tubulin (Sigma) were used to normalise for equal loading.

\subsection{Histone extraction protocol}

Cells were harvested and washed twice with ice-cold PBS and lysed in Triton Extraction Buffer (TEB: PBS containing 0.5\% Triton $\mathrm{X} 100(\mathrm{v} / \mathrm{v}), 2 \mathrm{mM}$ phenyl methyl sulfonyl fluoride (PMSF), 0.02\% $\left.(\mathrm{w} / \mathrm{v}) \mathrm{NaN}_{3}\right)$ at a cellular density of $10^{7}$ cells per $\mathrm{mL}$ for $10 \mathrm{~min}$ on ice, with gentle stirring. After a brief centrifugation at $2000 \mathrm{rpm}$ at $4{ }^{\circ} \mathrm{C}$, the supernatant was removed and the pellet was washed in half the volume of TEB and centrifuged as before. The pellet was resuspended in $0.2 \mathrm{M} \mathrm{HCl}$ at a cell density of $4 \times 10^{7}$ cells per $\mathrm{mL}$ and acid extraction was left to proceed overnight at $4{ }^{\circ} \mathrm{C}$ on a rolling table. Next, the samples were centrifuged at $2000 \mathrm{rpm}$ for $10 \mathrm{~min}$ at $4{ }^{\circ} \mathrm{C}$, the supernatant was removed and protein content was determined using the Bradford assay.

\subsection{Determination of histone $\mathrm{H} 3$ specific acetylations}

For the histone $\mathrm{H} 3$ acetylation in U937 cells, $10 \mu \mathrm{g}$ of histone extract was separated on $15 \%$ polyacrylamide gels and blotted. Western blots were shown for pan-acetylated histone $\mathrm{H} 3$ (Upstate).

\subsection{Fluorimetric human recombinant HDAC1 assays}

GST-HDAC1 has been cloned into the pAcG2T baculovirus transfer vector (BD) and purified by using glutathione beads. The BD BaculoGold transfection system (BD) has been used in Sf9 insect cells for expression following supplier's instructions. The HDAC assay has been carried out as follows: the HDAC Fluorescent Activity Assay is based on the Fluor de Lys Substrate and Developer combination (BioMol) and has been carried out according to supplier's instructions. Briefly, the Fluor de Lys Substrate, which comprises an acetylated lysine side chain, has been incubated with the purified recombinant HDAC enzymes in presence or absence of the inhibitors, for $0.5 \mathrm{~h}$ at $37^{\circ} \mathrm{C}$. When a different incubation time has been used, it is specified into the text. Deacetylation of the substrate sensitizes the substrate so that, in the second step, treatment 
with the Developer for 30 min produces a fluorophore. The fluorophore is excited with a $360 \mathrm{~nm}$ light and the emitted light $(460 \mathrm{~nm})$ has been quantified with a TECAN Inphinite M200 station.

\subsection{Human recombinant Sirt1 assay}

Recombinant human Sirt1 was prepared in E. coli BL21 and purified by affinity chromatography. The enzymatic reaction consisted of $1 \mu \mathrm{g}$ of Sirt 1 incubated with the acetylated p53 peptide (AA 379-382), $1 \mathrm{mM}$ dithiothreitol, and a range of inhibitor concentrations, as described. Reactions were carried out at $37^{\circ} \mathrm{C}$ for $60 \mathrm{~min}$. Assays were performed in the presence of $200 \mu \mathrm{M} \mathrm{NAD}^{+}$for each inhibitor. Fluorescence was measured with a fluorimetric reader (TECAN Inphinite M200 fluorescence plate reader) with excitation set at $360 \mathrm{~nm}$ and emission detection set at $450 \mathrm{~nm}$. Results are expressed as the mean and standard deviation of four independent experiments as percentage of activity considering the untreated control as 100 .

\subsection{Human recombinant CBP assay}

The recombinant CBP was prepared in E. coli BL21 and purified by affinity chromatography. Recombinant CBP fraction corresponded to amino acids 1098-1877. CBP was incubated in HAT buffer with $10 \mu \mathrm{g}$ of histone $\mathrm{H} 4$ peptide (corresponding to amino acids 2-24) and $20 \mu \mathrm{M}$ Acetyl CoA containing $0.5 \mu \mathrm{Ci} / \mathrm{mL}\left[{ }^{3} \mathrm{H}\right]-$ Acetyl CoA in the presence of inhibitors. After $2 \mathrm{~h}$ a $37^{\circ} \mathrm{C}, 5 \mu \mathrm{L}$ of samples were spotted onto Whatman P81 paper (in triplicate). The paper squares were washed three times in 5\% TCA and once in $100 \%$ acetone and then placed into scintillation vials containing scintillation fluid to allow the DPM reading. The DPM of enzyme samples was compared to DPM of negative control. Data have been expressed as percentage of activity considering the control without treatment as 100 .

\subsection{Human recombinant DNMT3A radioactive assay}

DNMT3A was produced in E. coli BL21 according to standard procedures. The methyltransferase radioactive assay was performed in a volume of $25 \mu \mathrm{L} /$ point, using $\left[{ }^{3} \mathrm{H}\right]$-adenosyl-L-methionine $(1 \mu \mathrm{Ci})$ as methyl donor and Poly dI-dC $(0.1 \gamma)$ as methyl acceptor, while $30-50 \mathrm{ng}$ of recombinant DNMT3A protein was used, depending on enzyme activity, stability and purity. The compounds were tested at $50 \mu \mathrm{M}$. After $2 \mathrm{~h}$ incubation at $37^{\circ} \mathrm{C}, 5 \mu \mathrm{L}$ of samples were spotted onto Whatman DE81 paper (in triplicate). The paper squares were washed three times in $5 \% \mathrm{Na}_{2} \mathrm{HPO}_{4}$ and once in sterile water and then placed into scintillation vials containing $5 \mathrm{~mL}$ of scintillation fluid to allow the DPM reading. The DPM of enzyme samples was compared to the DPM of negative control. Data were expressed as a percentage of activity relative to control.

\subsection{Immunoprecipitation of DNMT1 and radioactive assay}

The K562 cells were cultured in the experimental conditions reported and lysed in TAP buffer $\mathrm{pH} 7-7.5$ (50 mM Tris $\mathrm{pH} 7.0$, $180 \mathrm{mM} \mathrm{NaCl}, 0.15 \% \mathrm{v} / \mathrm{v} \mathrm{NP} 40,10 \% \mathrm{v} / \mathrm{v}$ glycerol, $1.5 \mathrm{mM} \mathrm{MgCl}_{2}$, $1 \mathrm{mM} \mathrm{Na}_{2} \mathrm{MoO}_{4}, 0.5 \mathrm{mM} \mathrm{NaF}, 1 \mathrm{mM}$ DTT, $0.2 \mathrm{mM}$ PMSF, $0.1 \mathrm{mM}$ protease inhibitor cocktail) for $10 \mathrm{~min}$ in ice and centrifuged at $130,000 \mathrm{rpm}$ for $30 \mathrm{~min}$. $650 \mu \mathrm{g}$ of extracts were diluted in TAP buffer up to $1 \mathrm{~mL}$ and pre-cleared by incubating with $20 \mu \mathrm{L} \mathrm{A/G}$ plus agarose (Santa Cruz) for $30 \mathrm{~min}$ to $1 \mathrm{~h}$ on a rocking table at $4{ }^{\circ} \mathrm{C}$. Supernatant was transferred to a new tube and 3-5 $\mu \mathrm{g}$ of antibody against DNMT1 (Abcam) was added. IP was allowed to proceed overnight at $4{ }^{\circ} \mathrm{C}$ on a rocking table. As a negative control the same amount of protein extracts were immunoprecipitated with purified IgG rabbit (Santa Cruz). The following day, $50 \mu \mathrm{L} \mathrm{A/}$ $\mathrm{G}$ plus agarose were added and incubation was continued for $2 \mathrm{~h}$. The beads were recovered by brief centrifugation and washed with cold TAP buffer several times. After the last washing $20 \mu \mathrm{L}$ of $2 \mathrm{X}$ concentrated electrophoresis sample buffer $(217 \mathrm{mM}$ Tris- $\mathrm{HCl} \mathrm{pH}$ 8.0, 5.3\% SDS, $17.4 \%$ glycerol, $8.7 \% \beta$-mercaptoethanol, $0.026 \%$ bromophenol blue) was added and the sample was boiled for $5 \mathrm{~min}$. A fraction of supernatants was loaded onto an SDS-PAGE gel in order to check the immunoprecipitation product. $10 \mu \mathrm{L}$ of resin binding DNMT1 were used in DNMT radioactive assay (see above) to test the inhibitory potency of the PsA derivatives.

\section{Acknowledgments}

This work was supported by the EU (Epitron LSHC-CT2005518417; JG, RP, GLF and AN contracts; and ATLAS Contract 221952), the Spanish MICINN (SAF-07-63880-FEDER), Xunta de Galicia (INBIOMED), and the Italian Associazione Italiana per la ricerca contro il cancro.

\section{Supplementary data}

Supplementary data associated with this article can be found, in the online version, at doi:10.1016/j.bmc.2010.12.026.

\section{References and notes}

1. Peng, J.; Li, J.; Hamann, M. T. Alkaloids: Chem. Biol. 2005, 61, 59.

2. Jiménez, C.; Crews, P. Tetrahedron 1991, 47, 2097.

3. Piña, I. C.; Gautschi, J. T.; Wang, G. Y. S.; Sanders, M. L.; Schmitz, F. J.; France, D.; Cornell-Kennon, S.; Sambucetti, L. C.; Remiszewski, S. W.; Perez, L. B.; Bair, K. W.; Crews, P. J. Org. Chem. 2003, 68, 3866.

4. Arabshahi, L.; Schmitz, F. J. J. Org. Chem. 1987, 52, 3584

5. Rodriguez, A. D.; Akee, R. K.; Scheuer, P. J. Tetrahedron Lett. 1987, 28, 4989.

6. Quiñoà, E.; Crews, P. Tetrahedron Lett. 1987, 28, 3229.

7. Suzuki, A.; Matsunaga, K.; Shin, H.; Tabudrav, J.; Shizuri, Y.; Ohizumi, Y. J. Pharmacol. Exp. Ther. 2000, 292, 725.

8. Shin, J.; Lee, H. S.; Seo, Y.; Rho, J. R.; Cho, K. W.; Paul, V. J. Tetrahedron 2000, 56, 9071.

9. Pham, N. B.; Butler, M. S.; Quinn, R. J. J. Nat. Prod. 2000, 63, 393.

10. Tabudravu, J. N.; Eijsink, V. G. H.; Gooday, G. W.; Jaspars, M.; Komander, D.; Legg, M.; Synstad, B.; Van Aalten, D. M. F. Bioorg. Med. Chem. 2002, 10, 1123.

11. Jung, J. H.; Sim, C. J.; Lee, C.-O. J. Nat. Prod. 1995, 58, 1722.

12. Park, Y.; Liu, Y.; Hong, J.; Lee, C. O.; Cho, H.; Kim, D. K.; Im, K. S.; Jung, J. H. J. Nat. Prod. 2003, 66, 1495.

13. Kim, D.; Lee, I. S.; Jung, J. H.; Yang, S. I. Arch. Pharm. Res. 1999, 22, 25.

14. Kim, D.; Lee, I. S.; Jung, J. H.; Lee, C. O.; Choi, S. U. Anticancer Res. 1999, 19, 4085 .

15. Nicholas, G. M.; Eckman, L. L.; Ray, S.; Hughes, R. O.; Pfefferkorn, J. A.; Barluenga, S.; Nicolaou, K. C.; Bewley, C. A. Bioorg. Med. Chem. Lett. 2002, 12, 2487.

16. Jiang, Y.; Ahn, E. Y.; Ryu, S. H.; Kim, D. K.; Park, J. S.; Yoon, H. J.; You, S.; Lee, B. J.; Lee, D. S.; Jung, J. H. BMC Cancer 2004, 4, 70.

17. Fajas, L.; Egler, V.; Reiter, R.; Hansen, J.; Kristiansen, K.; Debril, M.-B.; Miard, S.; Auwerx, J. Dev. Cell 2002, 3, 903.

18. Fajas, L.; Egler, V.; Reiter, R.; Miard, S.; Lefebvre, A.-M.; Auwerx, J. Oncogene 2003, 22, 4186.

19. Fu, M.; Rao, M.; Bouras, T.; Wang, C.; Wu, K.; Zhang, X.; Li, Z.; Yao, T.-P.; Pestell, R. G. J. Biol. Chem. 2005, 280, 16934.

20. Mora, F. D.; Jones, D. K.; Desai, P. V.; Patny, A.; Avery, M. A.; Feller, D. R.; Smillie, T.; Zhou, Y. D.; Nagle, D. G. J. Nat. Prod. 2006, 69, 547.

21. Shim, J. S.; Lee, H.-S.; Shin, J.; Kwon, H. J. Cancer Lett. 2004, 203, 163

22. Allis, C. D.; Jenuwein, T.; Reinberg, D.; Caparros, M.-L. Epigenetics; Cold Spring Harbor Laboratory Press: Cold Spring Harbor (NY), 2007.

23. Sippl, W.; Jung, M. In Epigenetic Targets in Drug Discovery: Methods and Principles of Medicinal Chemistry; Mannhold, R., Kubinyi, H., Folkers, G., Eds.; Wiley: Weinhem, 2009; Vol. 42.

24. Archer, S. Y.; Hodin, R. A. Curr. Opin. Gene Dev. 1999, 9, 171.

25. Marks, P. A.; Rifkind, R. A.; Richon, V. M.; Breslow, R.; Miller, T.; Kelly, W. K. Nat. Rev. Cancer 2001, 1, 194.

26. Rosato, R. R.; Grant, S. Cancer Biol. Ther. 2003, 2, 30.

27. Blanchard, F.; Chipoy, C. Drug Discovery Today 2005, 10, 197.

28. Bolden, J. E.; Peart, M. J.; Johnstone, R. W. Nat. Rev. Drug Disc. 2006, 5, 769.

29. Lin, H. Y.; Chen, C. S.; Lin, S. P.; Weng, J. R.; Chen, C. S. Med. Res. Rev. 2006, 26, 397.

30. Mei, S.; Ho, A. D.; Mahlknecht, U. Int. J. Oncol. 2004, 25, 1509. 
31. Minucci, S.; Pelicci, P. G. Nat. Rev. Cancer 2006, 6, 38.

32. Fouladi, M. Cancer Invest. 2006, 24, 521.

33. Botrugno, O. A.; Santoro, F.; Minucci, S. Cancer Lett. 2009, 280, 134.

34. Mai, A.; Altucci, L. Int. J. Biochem. Cell Biol. 2009, 41, 199.

35. Kazantsev, A. G.; Thompson, L. M. Nat. Rev. Drug Disc. 2008, 7, 854.

36. Marks, P. A.; Dokmanovic, M. Expert Opin. Invest. Drugs 2005, 14, 1497.

37. Drummond, D. C.; Noble, C. O.; Kirpotin, D. B.; Guo, Z.; Scott, G. K.; Benz, C. C. Ann. Rev. Pharmacol. Toxicol. 2005, 45, 495.

38. Rodriquez, M.; Aquino, M.; Bruno, I.; De Martino, G.; Taddei, M.; Gomez Paloma, L. Curr. Med. Chem. 2006, 13, 1119.

39. Paris, M.; Porcelloni, M.; Binaschi, M.; Fattori, D. J. Med. Chem. 2008, 51, 1505

40. Smith, K. T.; Workman, J. L. Int. J. Biochem. Cell Biol. 2009, 41, 21.

41. Witt, O.; Lindemann, R. Cancer Lett. 2009, 280, 123.

42. Klose, R. J.; Bird, A. P. Trends Biochem. Sci. 2006, 31, 89.

43. Ooi, S. K. T.; Bestor, T. H. Cell 2008, 133, 1145.

44. Baylin, S.; Bestor, T. H. Cancer Cell 2002, 1, 299.

45. Esteller, M. Oncogene 2002, 21, 5427.

46. Das, P. M.; Singal, R. J. Clin. Oncol. 2004, 22, 4632.

47. Baylin, S. B. Nat. Clin. Pract. Oncol. 2005, 2, S4.

48. Brueckner, B.; Lyko, F. Trends Pharm. Sci. 2004, 25, 551.

49. Kaminskas, E.; Farrell, A.; Abraham, S.; Baird, A.; Hsieh, L.-S.; Lee, S.-L.; Leighton, J. K.; Patel, H.; Rahman, A.; Sridhara, R.; Wang, Y.-C.; Pazdur, R. Clin. Cancer Res. 2005, 11, 3604

50. Morphy, R.; Kay, C.; Rankovic, Z. Drug Discovery Today 2004, 9, 641.

51. Morphy, R.; Rankovic, Z. J. Med. Chem. 2005, 48, 6523.

52. Remiszewski, S. W. Curr. Med. Chem. 2003, 10, 2393.

53. Hoshino, O.; Murakata, M.; Yamada, K. Bioorg. Med. Chem. Lett. 1992, 2, 1561.

54. Nicolaou, K. C.; Hughes, R.; Pfefferkorn, J. A.; Barluenga, S. Chem. Eur. J. 2001, 7 4296

55. Nicolaou, K. C.; Hughes, R.; Pfefferkorn, J. A.; Barluenga, S.; Roecker, A. J. Chem. Eur. J. 2001, 7, 4280.

56. Godert, A. M.; Angelino, N.; Woloszynska-Read, A.; Morey, S. R.; James, S. R.; Karpf, A. R.; Sufrin, J. R. Bioorg. Med. Chem. Lett. 2006, 16, 3330.

57. Boehlow, T. R.; Spilling, C. D. Nat. Prod. Lett. 1995, 7, 1.

58. Boehlow, T. R.; Harburn, J. J.; Spilling, C. D. J. Org. Chem. 2001, 66, 3111.

59. Carreño, M. C. R.; J.L.G.; Sanz, G.; Toledo, M. A.; Urbano, A. Synlett 1997, 1241.

60. Pfammatter, M. J.; Siljegovic, V.; Darbre, T.; Keese, R. Helv. Chim. Acta 2001, 84, 678.

61. Nishiyama, S.; Yamamura, S. Tetrahedron Lett. 1982, 23, 1281.

62. Forrester, A. R. T.; R.H.; Woo, S. O. J. Chem. Soc., Perkin Trans. 1 1975, 2340

63. Khan, N.; Jeffers, M.; Kumar, S.; Hackett, C.; Boldog, F.; Khramtsov, N.; Qian, X Mills, E.; Berghs, S. C.; Carey, N.; Finn, P. W.; Collins, L. S.; Tumber, A.; Ritchie J. W.; Jensen, P. B.; Lichenstein, H. S.; Sehested, M. Biochem. J. 2008, 409, 581

64. Bradner, J. E.; Mak, R.; Tanguturi, S. K.; Mazitschek, R.; Haggarty, S. J.; Ross, K Chang, C. Y.; Bosco, J.; West, N.; Morse, E.; Lin, K.; Shen, J. P.; Kwiatkowski, N. P.; Gheldof, N.; Dekker, J.; DeAngelo, D. J.; Carr, S. A.; Schreiber, S. L.; Golub, T. R.; Ebert, B. L. Proc. Natl. Acad. Sci. U.S.A. 2010, 107, 12617.

65. Balasubramanyam, K.; Swaminathan, V.; Ranganathan, A.; Kundu, T. K. J. Biol. Chem. 2003, 278, 19134.

66. (a) Souto, J. A.; Conte, M.; Alvarez, R.; Nebbioso, A.; Carafa, V.; Altucci, L.; de Lera, A. R. ChemMedChem 2008, 3, 1435; (b) Souto, J. A.; Bebedetti, R.; Otto, K; Miceli, M.; Alvarez, R.; Altucci, L.; de Lera, A. R. ChemMedChem 2010, 5, 1530; (c) Souto, J. A.; Vaz, E.; Lepore, I.; Pöppler, A.-C.; Franci, J. L.; Alvarez, R. Altucci, L.; de Lera, A. R. J. Med. Chem. 2010, 53, 4654.

67. Siedlecki, P.; Boy, R. G.; Musch, T.; Brueckner, B.; Suhai, S.; Lyko, F.; Zielenkiewicz, P. J. Med. Chem. 2006, 49, 678.

68. Datta, J.; Ghoshal, K.; Denny, W. A.; Gamage, S. A.; Brooke, D. G.; Phiasivongsa, P.; Redkar, S.; Jacob, S. T. Cancer Res. 2009, 69, 4277.

69. Biel, M.; Wascholowski, V.; Giannis, A. Angew. Chem., Int. Ed. 2005, 44 3186 .

70. Somoza, J. R.; Skene, R. J.; Katz, B. A.; Mol, C.; Ho, J. D.; Jennings, A. J.; Luong, C.; Arvai, A.; Buggy, J. J.; Chi, E.; Tang, J.; Sang, B. C.; Verner, E.; Wynands, R.; Leahy, E. M.; Dougan, D. R.; Snell, G.; Navre, M.; Knuth, M. W.; Swanson, R. V.; McRee, D. E.; Tari, L. W. Structure 2004, 12, 1325.

71. Bieliauskas, A. V.; Pflum, M. K. H. Chem. Soc. Rev. 2008, 37, 1402

72. McCulloch, M. W. B.; Coombs, G. S.; Banerjee, N.; Bugni, T. S.; Cannon, K. M.; Harper, M. K.; Veltri, C. A.; Virshup, D. M.; Ireland, C. M. Bioorg. Med. Chem. 2009, 17, 2189 .

73. Kim, D. H. S. J.; Kwon, H. J. Exp. Mol. Med. 2007, 39, 47.
74. Ahn, M. Y.; Jung, J. H.; Na, Y. J.; Kim, H. S. Ginecol. Oncol. 2008, 108, 27.

75. Richon, V. M.; Sandhoff, T. W.; Rifkind, R. A.; Marks, P. A. Proc. Natl. Acad. Sci. U.S.A. 2000, 97, 10014

76. Mai, A.; Massa, S.; Rotili, D.; Cerbara, I.; Valente, S.; Pezzi, R.; Simeoni, S.; Ragna, R. Med. Res. Rev. 2005, 25, 261.

77. Furumai, R.; Matsuyama, A.; Kobashi, N.; Lee, K. H.; Nishiyama, M.; Nakajima, H.; Tanaka, A.; Komatsu, Y.; Nishino, N.; Yoshida, M.; Horinouchi, S. Cancer Res. 2002, 62, 4916.

78. Xiao, J. J.; Byrd, J.; Marcucci, G.; Grever, M.; Can, K. K. Rapid Commun. Mass Spectrom. 2003, 17, 757.

79. Wang, D.; Helquist, P.; Wiest, O. J. Org. Chem. 2008, 72, 5446.

80. Nishino, N.; Jose, B.; Okamura, S.; Ebisusaki, S.; Kato, T.; Sumida, Y.; Yoshida, M. Org. Lett. 2003, 5, 5079 .

81. Nishino, N.; Shivashimpi, G. M.; Soni, P. B.; Bhuiyan, M. P. I.; Kato, T.; Maeda, S.; Nishino, T. G.; Yoshida, M. Bioorg. Med. Chem. 2008, 16, 437.

82. Bach, R. D.; Dmitrenko, O.; Thorpe, C. J. Org. Chem. 2008, 73, 12.

83. Rautio, J.; Kumpulainen, H.; Heimbach, T.; Oliyai, R.; Oh, D.; Järvinen, T.; Savolainen, J. Nat. Rev. Drug Disc. 2008, 7, 255.

84. Mai, A.; Cheng, D.; Bedford, M. T.; Valente, S.; Nebbioso, A.; Perrone, A.; Brosch, G.; Sbardella, G.; De Bellis, F.; Miceli, M.; Altucci, L. J. Med. Chem. 2008, $51,2279$.

85. Li, J. W. H.; Vederas, J. C. Science 2009, 325, 161

86. Newman, D. J. J. Med Chem 2008, 51, 2589.

87. Molinski, T. F.; Dalisay, D. S.; Lievens, S. L.; Saludes, J. P. Nat. Rev. Drug Disc. 2009, 8, 69.

88. Kotoku, N.; Tsujita, H.; Hiramatsu, A.; Mori, C.; Koizumi, N.; Kobayashi, M. Tetrahedron 2005, 61, 7211.

89. Knapp, S.; Amorelli, B.; Darout, E.; Ventocilla, C. C.; Goldman, L. M.; Huhn, R. A.; Minnihan, E. C. J. Carbohydr. Chem. 2005, 24, 103.

90. Frisch, M. J.; G. W. T., Schlegel, H. B.; Scuseria, G. E.; Robb, M. A.; Cheeseman, J. R.; Montgomery, Jr., J. A.; Vreven, T.; Kudin, K. N.; Burant, J. C.; Millam, J. M.; Iyengar, S. S.; Tomasi, J.; Barone, V.; Mennucci, B.; Cossi, M.; Scalmani, G.; Rega, N.; Petersson, G. A.; Nakatsuji, H.; Hada, M.; Ehara, M.; Toyota, K.; Fukuda, R.; Hasegawa, J.; Ishida, M.; Nakajima, T.; Honda, Y.; Kitao, O.; Nakai, H.; Klene, M.; Li, X.; Knox, J. E.; Hratchian, H. P.; Cross, J. B.; Bakken, V.; Adamo, C.; Jaramillo, J.; Gomperts, R.; Stratmann, R. E.; Yazyev, O.; Austin, A. J. Cammi, R.; Pomelli, C.; Ochterski, J. W.; Ayala, P. Y.; Morokuma, K.; Voth, G. A; Salvador, P.; Dannenberg, J. J.; Zakrzewski, V. G.; Dapprich, S.; Daniels, A. D.; Strain, M. C.; Farkas, Malick, O.; D. K.; Rabuck, A. D.; Raghavachari, K.; Foresman, J. B.; Ortiz, J. V.; Cui, Q.; Baboul, A. G.; Clifford, S.; Cioslowski, J.; Stefanov, B. B.; Liu, G.; Liashenko, A.; Piskorz, P.; Komaromi, I.; Martin, R. L.; Fox, D. J.; Keith, T.; Al-Laham, M. A.; Peng, C. Y.; Nanayakkara, A.; Challacombe, M.; Gill, P. M. W.; Johnson, B.; Chen, W.; Wong, M. W.; Gonzalez, C.; Pople, J. A. Gaussian, Pittsburg: 2004.

91. Bayly, C. I.; Cieplak, P.; Cornell, W. D.; Kollman, P. A. J. Phys. Chem. 1993, 97, 10269.

92. Cornell, W. D.; Cieplak, P.; Bayly, C. I.; Gould, I. R.; Merz, K. M.; Ferguson, D. M.; Spellmeyer, D. C.; Fox, T.; Caldwell, J. W.; Kollman, P. A. J. Am. Chem. Soc. 1995, 117, 5179.

93. Rodríguez-Barrios, F.; Pérez, C.; Lobatón, E.; Velázquez, S.; Chamorro, C.; SanFélix, A.; Pérez-Pérez, M. J.; Camarasa, M. J.; Pelemans, H.; Balzarini, J.; Gago, F. J. Med. Chem. 2001, 44, 1853 .

94. Morris, G. M.; Goodsell, D. S.; Halliday, R. S.; Huey, R.; Hart, W. E.; Belew, R. K.; Olson, A. J. J. Comput. Chem. 1998, 19, 1639.

95. Morris, G. M.; Goodsell, D. S.; Huey, R.; Hart, W. E.; Halliday, S.; Belew, R.; Olson, A. J.; AutoDock, 3.0 ed. La Jolla, CA, 1999.

96. Goodford, P. J. J. Med. Chem. 1985, 28, 849.

97. Åqvist, J. J. Phys. Chem. 1990, 94, 8021.

98. Jorgensen, W. L.; Chandrasekhar, J.; Madura, J. D. J. Chem. Phys. 1983, 79, 926. 99. http://amber.scripps.edu/doc8.

100. Ryckaert, J. P.; Ciccoti, G.; Berendsen, H. J. C. J. Comput. Phys. 1977, 23, 327.

101. Nebbioso, A.; Clarke, N.; Voltz, E.; Germain, E.; Ambrosino, C.; Bontempo, P.; Alvarez, R.; Schiavone, E. M.; Ferrara, F.; Bresciani, F.; Weisz, A.; de Lera, A. R.; Gronemeyer, H.; Altucci, L. Nat. Med. 2005, 11, 77.

102. Scognamiglio, A.; Nebbioso, A.; Manzo, F.; Valente, S.; Mai, A.; Altucci, L. Biochem. Biophys. Acta 2008, 1783, 203.

103. Altucci, L.; Rossin, A.; Raffelsberger, W.; Reitmair, A.; Chomienne, C.; Gronemeyer, H. Nat. Med. 2001, 7, 680. 